Allergic rhinitis is a condition which affects over $15 \%$ of the population in the United Kingdom. The pathological process involves two stages: nasal inflammation, and the development of nasal airway hyperresponsiveness (AHR) to allergen and a number of other stimuli. This results in the amplification of any subsequent allergic reaction, contributing to the chronic allergic state. A number of different hypotheses have been proposed to explain the underlying mechanism of AHR, including a role for eosinophilderived proteins, free radicals and neuropeptides. While there may be a number of independent pathways which can result in AHR, evidence obtained from both animal models and in vivo experiments in humans indicate that some mediators may interact with one another, resulting in AHR. Further research in to these interactions may open new avenues for the pharmacological treatment of chronic allergic rhinitis, and possibly other allergic airway diseases.

Key words: Human nasal airway, Hyperresponsiveness, Eosinophils, Bradykinin, Neuropeptides, Nitric oxide

\section{Hyperresponsiveness in the human nasal airway: new targets for the treatment of allergic airway disease}

\section{P. J. Turner and J. C. Foreman ${ }^{\mathrm{CA}}$}

Department of Pharmacology, University College London, Gower Street, London WC1E 6BT, UK

\author{
${ }^{\mathrm{CA}}$ Corresponding Author \\ Tel: $(+44) 1713807314$ \\ Fax: (+44) 1713807298 \\ Email: john.foreman@ucl.ac.uk
}

\section{Introduction}

Allergic rhinitis and asthma are two of the most common immunological disorders producing chronic disease in man. For instance, allergic rhinitis affects over $15 \%$ of the general population. ${ }^{1}$ In both diseases, a local allergic reaction results in an inflammatory response, causing wheezing and mucus secretion in asthma, and nasal congestion, rhinorrhoea ('runny nose'), pruritis (itching) of the nose and sneezing in allergic rhinitis. Continued exposure to allergen induces a state of chronic allergic inflammation. Contributing to this is the development of airway hyperresponsiveness (AHR), which results in the amplification of any subsequent allergic reaction.

While a variety of pharmacological agents can be used to treat the initial inflammatory response, only steroids are effective in preventing AHR. The mechanism by which AHR occurs remains unclear. If the mechanism of AHR can be described, then this may provide new pharmacological targets for the treatment of chronic allergic airw ay disease. While allergic rhinitis is not life-threatening, the same is not true for chronic asthma, and the problem is compounded by the adverse effects associated with long-term steroid use.

Unfortunately, animal models and in vitro experiments are of limited value, since they are not representative of the situation in man. ${ }^{2,3}$ However, the human nasal airway is reasonably accessible for in vivo research into the development of nasal AHR, and may also yield some insight into the mechanism of
AHR in asthma. We review here current hypotheses for the development of AHR in the human nose, and indicate potential new pharmacological targets for the treatment of allergic rhinitis and possibly other allergic airway diseases.

\section{Pathogenesis of allergic rhinitis}

There are two distinct forms of allergic rhinitis, depending on the allergen to which the subject is sensitive. In perennial allergic rhinitis (PAR), the subject is exposed to allergen throughout the year, while in subjects with seasonal allergic rhinitis (SAR), allergen exposure is limited to certain times during the year. Subjects with PAR are sensitive to allergens including those from the house-dust mite (Dermatophagoides pteronyssinus), other mites, animal danders and certain foods. In contrast, the allergens involved in SAR are tree and grass pollens, moulds and certain fungal spores.

\section{Nasal inflammation}

When particles of allergen are inhaled into the nasal cavity, they cross the nasal mucosa and are exposed to the immune system; in susceptible individuals, this results in sensitisation, a process where immunoglobulin $\mathrm{E}$ (IgE) is synthesised and becomes fixed to cells, such as mast cells. If these cells subsequently encounter the same allergen, crosslinking occurs between $\operatorname{IgE}$ molecules on the cell surface, causing the release of inflammatory mediators including 
histamine, kinins and eicosanoids, such as $\mathrm{PGD}_{2},{ }^{4}$ as show $\mathrm{n}$ in Table 1 . These mediators are responsible for the symptoms of allergic rhinitis. Nasal blockage results from a combination of increased blood flow to the nose (causing swelling of the nasal tissue), plasma extravasation, and oedema. Rhinorrhoea is a consequence of the stimulation of nasal secretory glands, which produce a mixture of watery or serous secretion and viscous mucus secretion, mixed together with extravasated plasma. Stimulation of sensory nerves in the nasal cavity causes sneezing and pruritis.

One method used to study the inflammatory response in the human nose is nasal lavage, where the nasal cavity is rinsed with a solution (such as saline), and the lavage fluid subsequently collected and analysed. Using this technique, one can measure a number of inflammatory mediators using ap propriate assays. Furthermore, by collecting and counting cells present in the lavage fluid, it is possible to correlate the release of inflammatory mediators with the different cells observed.

The response of subjects with allergic rhinitis to intranasal challenge can often be divided into an immediate phase, occurring during the first $2 \mathrm{~h}$ follow ing exposure to antigen, and, in about $30-40 \%$ of subjects, a late phase occurring 6-12 h later. The late phase is associated with an infiltration of a number of different inflammatory cells (including eosinophils, neutrophils and T-lymphocytes) to the site of inflammation, where they release a variety of mediators including leukotrienes, cationic proteins such as eosinophil cationic protein (ECP), and cytokines (Table 1).

Interestingly, there may be differences in the precise mediators involved in PAR and SAR. While histamine is strongly associated with the early phase of SAR, histamine $\mathrm{H}_{1}$ antagonis ts are not very effective in reducing the early allergic response of PAR.

Table 1. Mediators found in nasal lavage fluid collected following both the immediate and late phase response in atopic individuals challenged intranasally with allergen ${ }^{4}$

\begin{tabular}{lcc}
\hline Mediator & $\begin{array}{c}\text { Immediate } \\
\text { phase }\end{array}$ & $\begin{array}{c}\text { Late } \\
\text { phase }\end{array}$ \\
\hline Histamine & $\checkmark \checkmark$ & $\checkmark \checkmark$ \\
TAME-esterase & $\checkmark \checkmark$ & $\checkmark \checkmark$ \\
Prostaglandin $\mathrm{D}_{2}$ & $\checkmark \checkmark$ & $x$ \\
Leukotrienes $\mathrm{LTB}_{4} / \mathrm{C}_{4} / \mathrm{D}_{4}$ & $\checkmark$ & $\checkmark$ \\
Kinins & $\checkmark \checkmark$ & $\checkmark$ \\
Platelet-activating factor (PAF) & $\checkmark$ & $x$ \\
Albumin & $\checkmark \checkmark$ & $\checkmark \checkmark$ \\
Neuropeptides, e.g. CGRP and VIP & $\checkmark$ & $x$ \\
Substance P & $\checkmark$ & $\checkmark$ \\
Eosinophil-derived mediators, & $x$ & $\checkmark \checkmark$ \\
$\quad$ e.g. ECP, MBP & & \\
Interleukin 1 (IL-1) & $\checkmark$ & $\checkmark$ \\
IL-3, IL-4, IL-5, IL-6, TNF $\alpha$ & $x$ & $\checkmark$ \\
\hline
\end{tabular}

Instead, the kinins appear to be the major mediator causing symptoms in PAR. ${ }^{5}$ There is also evidence that the allergen (house dust mite) in PAR can generate kinin independent of the inflammatory response, either by the direct activation of kallikrein, the enzyme which generates kinins, ${ }^{6}$ or by possessing such biochemical activity itself. ${ }^{7}$

\section{Nasal airway hyperresponsiveness}

Nasal hyperresponsiveness is a hallmark of allergic rhinitis. ${ }^{8,9}$ Subjects with allergic rhinitis show an increased response to nasal challenge with a variety of stimuli, including histamine and bradykinin, both of which are released following allergen challenge. The nasal airway effectively becomes more sensitive to allergen, contributing to the chronic allergic state. AHR is usually associated with the late phase reaction, but can continue well beyond this stage. In fact, it is induced irrespective of whether a late phase of inflammation occurs. ${ }^{10}$

One important consideration is the type of response involved in AHR. In asthma, AHR is often defined as an increase in the contractile response of the airway smooth muscle. However, there is little smooth muscle present in the human nasal airway. Nasal blockage results from increased blood flow to the nasal mucosa, and not by an action on smooth muscle. This highlights the difficulty of extrapolating data from the nasal airway to the lower airways, and vice versa. AHR is also associated with increased mucus production and oedema following allergen challenge, in both the upper and lower airways. Therefore, AHR would appear to result from a direct or indirect potentiation of the overall receptor activation, and not simply from an action on a particular cell type alone. With this in mind, there are a number of potential mechanisms by which AHR might occur (Fig. 1).

\section{(1) The inflam matory cascade:}

Initial exposure to allergen might trigger a cascade reaction, causing increased mediator release and, therefore, greater receptor activation. For instance, subjects with SAR experience increasingly severe symptoms as the pollen season continues. However, a number of inflammatory mediators can induce AHR in the absence of any other mediator. Furthermore, the development of AHR can occur independently of a chronic inflammatory response. ${ }^{10}$ It is likely, therefore, that the AHR potentiates the effect of the inflammatory cascade seen in chronic alle rgic rhinitis, rather than being caused by it.

\section{(2) Increased exposure of receptors on the nasal mucosa to the stimulus:}

A common histological finding in chronic airway allergy is the damage and shedding of epithelial cells 
Stimulus
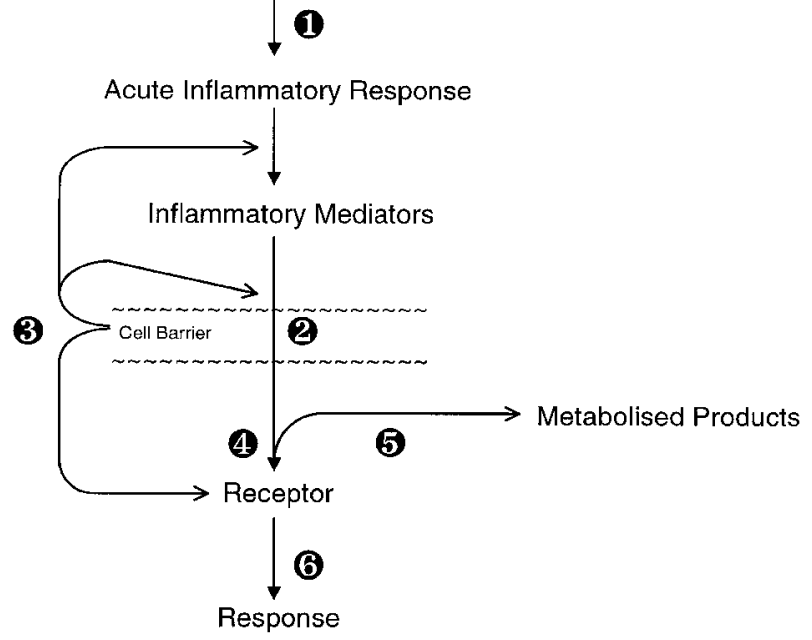

FIG. 1. Potential mechanisms in the development of AHR (1) Inflammatory Cascade; 2 altered exposure of the receptor to the stimulus; 3 release of modulating agent by other cells; (4) change in the receptor properties; 6 altered metabolism of the mediator; $\boldsymbol{\sigma}$ altered regulation of the intracellular signalling resulting in the response.

lining the airway. The airway epithelium can act as a physical barrier between the airway lumen and the underlying mucosa. Therefore, removal of these cells would increase the exposure of the receptors on the mucosa to any stimulus present. For example, in the lower airways, removal of the airway epithelium increases the response of smooth muscle in both animal models and human bronchi ex vivo. ${ }^{11}$ While there may be a link between epithelial shedding and the presence of AHR in allergic individuals, ${ }^{12}$ mediators which induce AHR on their own (e.g. plateletactivating factor) do not cause epithelial shedding in the time taken for AHR to develop, though the doses required are toxic to airway epithelial cells. ${ }^{13}$ Alternatively, the loss of airway epithelial cell function, but not necessarily barrier function, may be sufficient to induce AHR. ${ }^{14}$ In the human nasal airway, AHR to bradykinin is unlikely to be due to a reduction in epithelial barrier function, ${ }^{15}$ and there is no evidence for increased epithelial permeability in subjects with allergic rhinitis. ${ }^{16}$ Mediators such as PAF may also damage the mucociliary clearance system linked to the airway epithelium, contributing to the AHR. ${ }^{13}$

\section{(3) Modulating agents:}

The ability of acetylcholine to cause vasodilatation in the vascular system is dependent upon the release of nitric oxide from the endothelium (and possibly other mediators, collectively known as endotheliumderived relaxing factors). It has been proposed that airway epithelial cells may generate mediators, such as arachidonic acid metabolites, nitric oxide and the putative epithelium-derived relaxing factor (EpDRF) (also known as EDHF (epithelium-derived hyperpolarsing factor)) which modulate the responsiveness of the airways. However, the evidence for such mediator release from airway epithelial cells is equivocal. ${ }^{1,17-19}$ The epithelium may have an important role in the metabolism of various stimuli, particularly adenosine,$^{20}$ tachykinins ${ }^{18}$ and acetylcholine. ${ }^{21}$ Loss of epithelial cell function might reduce the metabolism of these mediators, enhancing their ability to activate receptors and effect a response. However, epithelial damage can occur without the presence of AHR, and vice versa. ${ }^{22}$ For example, cationic proteins can cause AHR without any apparent damage to the epithelium. ${ }^{23}$

\section{(4) Receptors:}

AHR may result from a change in the characteristics of receptors located on the nasal mucosa. For example, cholinergic agonists such as methacholine cause more secretion in allergic subjects than in non-allergic controls, and this could be explained by an increase in the density of cholinergic receptors. ${ }^{24}$ However, the density of muscarinic receptors on nasal tissue from allergic subjects may actually decrease slightly, possibly as a result of adaptation due to overstimulation, although the remaining receptors exhibit an increased affinity, which might contribute to the hypersecretion. ${ }^{25}$ No significant differences have been found for $\alpha$-or $\beta$-adrenoceptors. ${ }^{26}$ The minor changes observed are probably a result, rather than the cause, of AHR.

\section{(5) Metabolism:}

Alternatively, AHR may be a consequence of prolonged activity of a variety of mediators, due to an effect on their metabolism. For example, neuropeptides are degraded by neutral endopeptidase (NEP), and the activity of NEP is significantly lower in subjects with nasal AHR. ${ }^{27}$ A second protein, lactoferrin, may prevent antigen-induced AHR in the lower airways of sheep by inhibiting tryptase. ${ }^{28}$ Though the precise role of tryptase in airway alle rgy is not fully known, it can induce AHR in the lower airways of shee $\mathrm{p}^{29}$ and in $e x$ vivo tissue from human bronchi. ${ }^{30}$

\section{(6) Altered intracellular signalling:}

Finally, the intracellular pathways which are activated by the receptor/agonist complex may be altered in AHR. Of particular interest is phosphodiesterase IV (PDE4), an enzyme which catalyses the metabolism of a number of intracellular messengers, such as cyclic GMP (cGMP). While PDE4 inhibitors abolish AHR in animal models, ${ }^{31}$ the data in human asthmatic subjects are equivocal, ${ }^{32}$ and there are no data with respect to the human nasal airway. Interestingly, inhibitors of nitric oxide synthase can also cause AHR, possibly by reducing the amount of cGMP. ${ }^{33}$ AHR could result from a loss of a compensatory mechanism, involving cGMP; such a mechanism may be free radical dependent. ${ }^{34}$ In the chronic allergic state, AHR 
may result, in part, from a change in gene transcription within cells (e.g. the NF-kB transcription system), though the timescale of onset of hyperresponsiveness makes this process unlikely in the induction of AHR.

\section{Mediators implicated in the development of AHR}

In 1933, Sir Henry Dale described a number of criteria which should be used to identify potential inflammatory mediators. Applying these to the development of AHR:

- administration of the potential mediator should cause AHR in vitro and in vivo;

- the mediator should be present in appropriate concentrations in allergic individuals with AHR;

- the mechanisms involved in the generation of the mediator should be present and increased in AHR;

- a mechanism should exist to terminate the action of the mediator (important, because AHR is a reversible phenomenon);

- antagonists of the mediator reduce the induction of AHR;

- receptors/signalling pathways should be present in the nasal mucosa, and be activated by the mediator.

The process by which AHR occurs remains unclear, no doubt due, in part, to the complexity of the mechanism and the difficulty in regulating the process under controlled experimental conditions. Nonetheless, because it is associated with the influx of cells to the site of inflammation, a number of hypotheses have been proposed involving mediators released from these cells. One particular cell type, the eosinophil, has been implicated in AHR. In both SAR and PAR, antigen challenge results in an increase of eosinophils in the nasal mucosa and the release of various eosinophil-derived mediators. ${ }^{35-39}$ Consequently a major role has been proposed for eosinophils and their proteins in this process.

\section{Eosinophil granule-derived proteins}

Eosinophils contain granules composed of four basic proteins. The core of these granules is major basic protein $(\mathrm{MBP})$, while the matrix surrounding the core is composed of eosinophil cationic protein (ECP), eosinophil-derived ne urotox in (EDN) and eosinophil peroxidase (EPO). ${ }^{40}$ The possible roles of these proteins in allergic airway disease are described in Table 2 .

The levels of ECP, EPO and MBP are raised follow ing antigen challenge in allergic rhinitis, $37-39,41$ and these increases often coincide with the presence of AHR. MBP and other cationic proteins, including
Table 2. Cationic proteins found in eosinophil granules ${ }^{40}$

\begin{tabular}{|c|c|c|}
\hline Protein & $\begin{array}{l}\text { Cell content } \\
\text { ( } \mu \mathrm{g} / 10^{6} \text { cells) }\end{array}$ & Role in allergic airway disease \\
\hline MBP & 9 & $\begin{array}{l}\text { - causes histamine release from } \\
\text { basophils and mast cells } \\
\text { - cytotoxic for human epithelial } \\
\text { cells } \\
\text { - causes bronchoconstriction and } \\
\text { induces hyperresponsiveness in } \\
\text { animals } \\
\text { - activates neutrophils }\end{array}$ \\
\hline ECP & 5 & $\begin{array}{l}\text { - causes histamine release from } \\
\text { mast cells } \\
\text { - cytotoxic to a variety of cells }\end{array}$ \\
\hline EDN & 3 & - undefined \\
\hline EPO & 12 & $\begin{array}{l}\text { - cytotoxic to airway epithelium } \\
\text { provokes bronchoconstriction } \\
\text { in animals } \\
\text { - in the presence of } \mathrm{H}_{2} \mathrm{O}_{2} \text { and } \\
\text { halide, causes mast cell } \\
\text { degranulation and histamine } \\
\text { release and inactivates } \\
\text { leukotrienes }\end{array}$ \\
\hline
\end{tabular}

the synthetic protein poly-t-lysine, cause AHR in the lower airways of rats, ${ }^{23}$ which appears to be dependent on their cationic charge. However, no study has yet been conducted to investigate whether these cationic proteins can themselves induce AHR in the human nasal airway.

The mechanism of MBP-induced AHR is unknown, though it may be dependent on causing epithelial damage, since MBP only induces AHR in guinea pig tracheal preparations with an intact epithelium. ${ }^{42}$ However, as stated above, cationic proteins may induce AHR without causing epithelial damage. ${ }^{23}$ Furthermore, although all the eosinophilic cationic proteins are cytotoxic to the airway epithelium, ${ }^{43}$ only MBP caused AHR in a study on primates.$^{44}$ In the lower airway of the rat, AHR induced by MBP or polyL-lysine is abolished by both neurokinin NK-1 ${ }^{45}$ and bradykinin $\mathrm{B} 2^{46}$ antagonists, indicating a role for substance $\mathrm{P}$ and the kinins in the development of AHR. It is also possible that eosinophil cationic proteins act on other inflammatory cells to generate the conditions required for AHR. ${ }^{22}$ While there is evidence for a relationship between ECP levels in nasal lavage and nasal AHR, ${ }^{47}$ th is has not always been reproduced in other studies ${ }^{48,49}$ so ECP is unlikely to be solely responsible for the induction of nasal AHR.

\section{Platelet activating factor (PAF)}

PAF is a naturally occurring phospholipid, and is the only endogenous compound know $\mathrm{n}$ to induce AHR in both animals and man. ${ }^{50}$ In normal, non-atopic subjects, it induces a nasal AHR to histamine and bradykinin ${ }^{51,52}$ and causes an increased response to pollen in subjects with SAR. ${ }^{51}$ The resulting AHR is 
similar, in many ways, to that observed in allergic rhinitis, as PAF also causes a significant nasal neutrophilia and eosinophilia, together with raised ECP levels in nasal lavage fluid. ${ }^{52-54}$

Although PAF can induce AHR in the human nasal airw ay, its role in allergen-induced AHR is less defined. Antigen challenge with grass pollen in atopic individuals with SAR causes the release of lyso-PAF and $\mathrm{PAF}^{41,55}$ but it is unclear whe ther PAF or lyso-PAF are released in $\mathrm{PAR},{ }^{56}$ One possibility is that any $\mathrm{PAF}$ generated is converted to lyso-PAF by acetylhydrolase present in the lavage fluid. The activity of this enzyme in lavage fluid is significantly raised following grass pollen challenge in sensitive subjects. ${ }^{41,57}$

PAF may act directly on the nasal mucosa, and radioligand binding studies indicate the presence of specific binding sites for PAF in human lung tissue, ${ }^{58}$ but no such studies have yet been performed using tissue obtained from the human nose. One of the main features of PAF is its ability to attract and activate a variety of inflammatory cells, including eosinophils, neutrophils, monocytes, macrophage and platelets. ${ }^{50}$ PAF may also release from airway epithelial cells a range of chemotactic factors for neutrophils and eosinophils, including the cytokine GM-CSF. ${ }^{59}$ The subsequent activation of these cells will release a range of mediators which can act on other cells in the airway. Administration of PAF into the nasal airway also causes ECP release, which could then contribute to the AHR. ${ }^{52,53}$

If PAF is an important mediator of nasal AHR, one would expect PAF-antagonists to reduce leukocyte infiltration and inhibit antigen-induced AHR. While this effect has been observed in some studies using animal models, ${ }^{60-62}$ the PAF antagonists WEB $2086^{41}$ and UK $74,505^{63}$ did not alter AHR in the human nasal airway. How ever, both these antagonis ts exhibit a low potency for PAF receptors, and may cause only a weak inhibitory action in man.

PAF causes mucosal dysfunction and damage, inhibiting ciliary action and increasing exfoliation of the epithelial lining of the airway both in vivo in the lower airways of the rabbit ${ }^{13}$ and in vitro using explants from human nasal mucosa. ${ }^{64}$ Interestingly, the latter study found that PAF is itself cytotoxic to epithelial cells, without requiring the production of other cytotoxic mediators. PAF-induced AHR in the human nasal airway was almost abolished by pretreatment with the antioxidant vitamin $E^{52}$ implying a mechanism which is dependent on the generation of free radicals. This supports the hypothesis that PAF causes tissue damage which may be independent of the release of other mediators, perhaps via the generation of free radicals. The source of the free radicals could be the epithelial cells, so in effect, the epithelium may cause its own destruction. ${ }^{65}$

It is unclear, however, whether sufficient quantities of PAF are produced in the antigen-induced allergic response to cause $\mathrm{AHR}$, and there are probably differences in the underlying mechanism of AHR induced by PAF and antigen.

\section{Leukotrienes}

The leukotrienes are generated by the action of 5-lipoxygenase on arachidonic acid. They are released in both the early and late phases following antigen challenge in subjects with SAR $^{66}$ and during the early phase in PAR. ${ }^{67}$ There are two classes of leukotrienes: $\mathrm{LTB}_{4}$ and the peptidyl-cysteinyl leukotrienes ( $\mathrm{LTC}_{4}$, $\mathrm{LTD}_{4}$ and $\left.\mathrm{LTE}_{4}\right)$. The latter group are synthesised by eosinophils (among other cells) and cause a longlasting eosinophilic infiltration, and have been associated w ith AHR in the lower airways in rats ${ }^{68}$ and in man; ${ }^{69}$ both these actions appear to be dependent on eosinophil activation. Although inhibitors of leukotriene synthesis reduce the nasal blockage experienced following challenge with grass pollen in allergic subjects, ${ }^{70,71}$ no studies have investigated the effect of such drugs on AHR in the human nasal airway, though zileuton, a lipoxygenase inhibitor, reduced antigen-induced AHR in the lower airways of asthmatics. ${ }^{72}$ Pharmacological intervention can also be achieved at the level of the receptor, and a number of leukotriene receptor antagonists have been developed which inhibit AHR in animal models. ${ }^{73}$ Many of these are currently under study in man, including pranlukast, which may reduce AHR in asthmatics, ${ }^{74}$ and montelukast, which has recently been approved for use in the USA. The role of $\mathrm{LTB}_{4}$ in AHR is not clear, but $\mathrm{LTB}_{4}$ antagonists have been shown to inhibit antigen-induced AHR in the lower airways of primates ${ }^{75}$ and the guinea pig. ${ }^{76}$ Although human eosinophils cannot produce $\mathrm{LTB}_{4}$ because they lack the enzyme needed for its synthesis, it is the main lipoxygenase product in neutrophils, and acts as a potent stimulus for leukocyte infiltration and subsequent degranulation. ${ }^{77}$

\section{Prostaglandins and thromboxanes}

The prostaglandins $\mathrm{PGD}_{2}$ and $\mathrm{PGE}_{2}$ are detected at increased levels in nasal lavage fluid following allergen challenge in subjects with $\mathrm{SAR}^{78,79}$ and PAR, ${ }^{80}$ but only in the early response and not the late phase of inflammation. ${ }^{66}$ Inhibitors of cyclooxygenase, the enzyme required for the synthesis of prostaglandins, do not affect the response to antigen in the human nasal airway. ${ }^{66} \mathrm{PGE}_{2}$ is synthesised by the airway epithelium and has been proposed as a possible EpDRF. In the lower airways, AHR may result from epithelial damage, reducing $\mathrm{PGE}_{2}$ generation by epithelial cells and, therefore, decreasing its relaxant effect on airway smooth muscle. ${ }^{81}$ However, in the human nose, any action of $\mathrm{PGE}_{2}$ would presumably have to be on blood vessels (since there is little airway 
smooth muscle in the human nose), and one would also expect a decrease in $\mathrm{PGE}_{2}$ release if it was involved in AHR, yet the opposite is true. Thromboxane $A_{2}\left(\mathrm{Tx}_{2}\right)$ does appear to mediate $\mathrm{AHR}$ in animal models ${ }^{82,83}$ and may do likew ise in man. ${ }^{84}$ Inhibition of thromboxane synthesis reduces AHR and also inhibits airway eosinophilia after allergen challenge. ${ }^{85}$ The thromboxanes may, therefore, have an important role in upregulating the eosinophil-associated response. ${ }^{77}$ The contribution of thromboxanes to nasal allergy remains undefined, and more research is needed to investigate their potential role in the development of AHR.

\section{Neuropeptides}

Sensory nerve fibres contain a number of different peptides, including calcitonin gene-related peptide (CGRP) and the tachykinins substance $\mathrm{P}$ (sub P) and neurokinin A (NK-A). These neuropeptides, metabolised inter alia by the enzyme neutral endopeptidase (NEP), are released from sensory nerves which form part of the non-adrenergic non-cholinergic (NANC) nervous system, and are capable of generating a local axon reflex which causes an increase in vascular permeability, plasma leakage and subsequent tissue oedema. This response is known as neurogenic inflammation, and is mediated by the tachykinin NK-1 and NK-2 receptors. In addition, eosinophils are capable of producing vasoactive intestinal peptide (VIP) and sub P. ${ }^{86}$ All these ne uropeptides are found in nasal secretions following nasal challenge with grass pollen, ${ }^{87}$ but their role in AHR remains unclear. However, there is a correlation between the presence of AHR and the activity of NEP in the human nose. ${ }^{27}$ Furthermore, in both PAR and SAR, AHR to bradykinin is mediated by neural reflexes, ${ }^{15}$ which could conceivably include a role for neuropeptides.

Neuropeptides appear to be important in AHR in a variety of animal models. In the lower airway of the rat, AHR induced by eosinophil-derived cationic proteins is inhibited by neurokinin NK-1 receptor antagonists and capsaicin. ${ }^{45}$ In the guinea pig, application of capsaicin to the lower airway (an action which depletes sensory nerves of neuropeptides) also abolishes antigen-induced AHR. ${ }^{88,89}$ The tachykinins, particularly sub $\mathrm{P}$, may enhance eosinophil recruitment ${ }^{90,91}$ and, therefore, cause $A H R$ via an eosinophil-dependent mechanism. However, the inhibition of AHR by capsaicin does not affect lipoxygenase activity or eosinophil infiltration, suggesting that neuropeptides cause AHR independently of, or after, eosinophil activation and leukotriene synthesis. ${ }^{89}$

Neurogenic inflammation may be a phenomenon only found in animals, since one study found no evidence of capsaicin-induced neurogenic inflammation in the human nasal airway. ${ }^{92}$ However, other studies, some utilising higher doses of capsaicin, confirm that neurogenic inflammation does occur in allergic rhinitis. ${ }^{93,94}$ Furthermore, application of capsaicin reduces the symptoms caused by antigen challenge in $\mathrm{SAR}^{95}$ and $\mathrm{PAR}^{96}$, though neither of these studies investigated AHR. It is, therefore, possible that AHR in the human nasal airway may result, at least in part, from an upregulation of neurogenic inflammation, possibly due to epithelial damage increasing the exposure of sensory nerves. Bradykinin causes neuropeptide release in vivo in the human nasal mucosa, ${ }^{97}$ while histamine has a similar effect on human lung tissue ex vivo. ${ }^{98}$ Damage to the airway epithelium may increase exposure of sensory nerves to stimuli, effectively causing an upregulation of neurogenic inflammation. This would result in increased neuropeptide release, which might further potentiate AHR, perhaps by direct effects on inflammatory cells (e.g. eosinophils) or by stimulating cytokine release from cells in the nasal mucosa, a process which occurs in the human nasal airway. ${ }^{99}$

Alternatively, neuropeptides may not just upregulate the inflammation resulting in AHR, but also directly cause the increased response observed in AHR. A number of stimuli, including antigen, cause neuropeptide release in the human nasal airway. If tachykinin activity is potentiated, due to more neuropeptide release or inhibition of metabolism, this would cause an increase in neuropeptide-mediated symptoms such as nasal obstruction and rhinorrhoea: in effect the 'hyper'-response observed in AHR. Phosphoramidon, a NEP inhibitor, can cause AHR in the lower airways of guinea pigs ${ }^{100}$ and man, ${ }^{101}$ and potentiates the activity of neuropeptides in the human nasal airway. ${ }^{102} \mathrm{NEP}$ is present in the human nasal mucosa, ${ }^{103}$ and correlates with the presence of nasal AHR. ${ }^{27}$ Epithelial damage may cause AHR by reducing the activity of NEP associated with airway epithelial cells. However, in the human nasal airway, PAF-induced AHR is not associated with the release of sub P (Fig. 2). PAF may cause AHR by a different mechanism to antigen, the former being independent of neuropeptide release. Alternatively, PAF may potentiate subsequent neuropeptide release from sensory nerves, and not cause neuropeptide release per se, so an increase in sub $\mathrm{P}$ would only occur in the presence of a further stimulus, such as histamine.

It is unknown which particular neuropeptides may be involved in the development of AHR. Sub P is the most potent endogenous mediator at the NK-1 receptor, but it does not induce $A H R$ in the lower airways of sheep, while NK-A does. ${ }^{104}$ In the human nasal airway, NK-1 receptors are localised to the epithelium, glands and blood vessels, while NK-2 receptors are limited to arterial vessels. ${ }^{105}$ This is in agreement with the findings that nasal obstruction is 


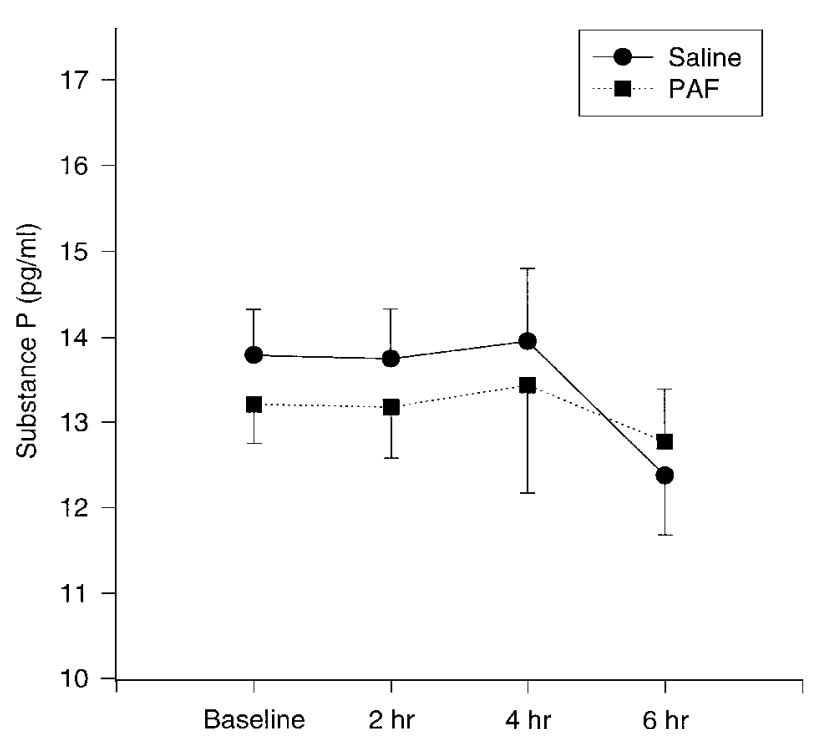

FIG. 2. The effect of PAF on the concentration of substance $P$ in nasal lavage fluid. The nasal airway was challenged with either saline or PAF, $60 \mu \mathrm{g}$, and the airway was lavaged 2, 4 and $6 \mathrm{~h}$ after challenge. Following lavage, a peptidase inhibitor was added to prevent degradation of substance $P$ prior to assay. Data are means-SEM from nine subjects.

mediated through the NK-1 receptor, while plasma extravasation probably involves both NK-1 and NK-2 receptor activation, ${ }^{106}$ and would explain the inconsistency that NK-1 or NK-2 receptor antagonists prevent AHR in some studies but not in others. In chronic asthma, both receptor subtypes are upregulated, ${ }^{107}$ and this may happen in chronic allergic rhinitis as well. There are no reports investigating the role of CGRP in AHR.

\section{Cytokines}

Cytokines are intercellular messenger peptides which are released by a variety of cells to influence the activity of other cells. Three cytokines are of vital importance in the development and regulation of eosinophil function: the interleukins IL-3 and IL-5, and granulocyte-macrophage colony-stimulating factor (GM-CSF). All three prevent apoptosis and prolong the survival of eosinophils in vitro, and in particular, IL-5 is essential for the differentiation of progenitor cells into eosinophils. ${ }^{108}$

Both IL-4 and IL-5 have been implicated in the development of AHR. ${ }^{109}$ In animals, IL-5 causes a marked eosinophilia, eosinophil activation and AHR. ${ }^{11}$ Monoclonal antibodies to IL-5 abolish antigen-induced eosinophilia and AHR in the lower airway of the guinea pig. ${ }^{110}$ IL 4 regulates the activity of $\mathrm{CD} 4+$ Tlymphocytes, which release a range of cytokines capable of priming and activating eosinophils, ${ }^{71}$ and can also activate neutrophils. ${ }^{11}$ Furthermore, memory T-cells in the nasal mucosa of patients with nasal allergy can produce IL 4 during allergen exposure, which may upregulate the inflammatory response. ${ }^{112}$
Patients with SAR or PAR have a raised number of CD4+ T-cells. ${ }^{113}$

Following nasal allergen challenge, the levels of IL$1 \alpha$, IL-1 $\beta$, IL-5, IL-6, IL- 8 and GM-CSF are raised in nasal secretions, ${ }^{114-116}$ and human eosinophils are potential sources of these cytokines. ${ }^{117}$ Epithelial cells, isolated from allergic rhinitics, showed increased immunostaining for GM-CSF, IL-8, the receptors for IL-1 and TNF- $\alpha,{ }^{118}$ and also they release more IL-1 $\beta$, IL- 8 , GM-CSF and TNF- $\alpha$ compared to epithelial cells from non-allergic subjects. ${ }^{19}$ Similar increases in IL-4-, IL-5- and GM-CSF-positive cells are observed in biopsies from the nasal mucosa of atopics. ${ }^{120}$ Both interferon- $\gamma$ and TNF- $\alpha$ (and possibly other cytokines) cause an upregulation of ICAM-1 on human nasal epithelial cells, ${ }^{121}$ while IL 4 upregulates the expression of VCAM-1. ${ }^{113}$ Both these adhesion molecule are upregulated in allergic rhinitis. ${ }^{113}$

Cytokines may promote AHR by upregulating the recruitment and activation of eosinophils (Fig. 3) and neutrophils. For example, there are close correlations between the number of eosinophils and GMCSF levels in bronchoalveolar fluid (BALF) from subjects with asthma, ${ }^{122}$ while the survival of eosinophils in BALF from subjects with allergic rhinitis correlates the concentrations of IL-5 and GM-CSF present. ${ }^{123}$ Neurokinin NK-2 receptor antagonists inhibit AHR induced by IL-5 in the guinea pig, but not the associated eosinophilia, ${ }^{124}$ indicating that cytokines are involved in cell recruitment, following which various mediators are released, such as neuropeptides which may cause the development of AHR. IL-1 may also be involved in the development of AHR, ${ }^{125}$ but it has a wide range of cellular actions, so it is difficult to suggest a precise role for it in the pathogenesis of AHR. Interestingly, it may inhibit the activity of $\mathrm{NEP}{ }^{126}$ or induce the generation of oxygen-based free radicals from macrophages and ne utrophils. ${ }^{127}$

Finally, glucocorticoids downregulate the production of IL-3 and IL-5 follow ing alle rgen challenge; this effect may contribute to the action of steroids in abolishing AHR, ${ }^{116}$ although glucocorticoids have other actions too.

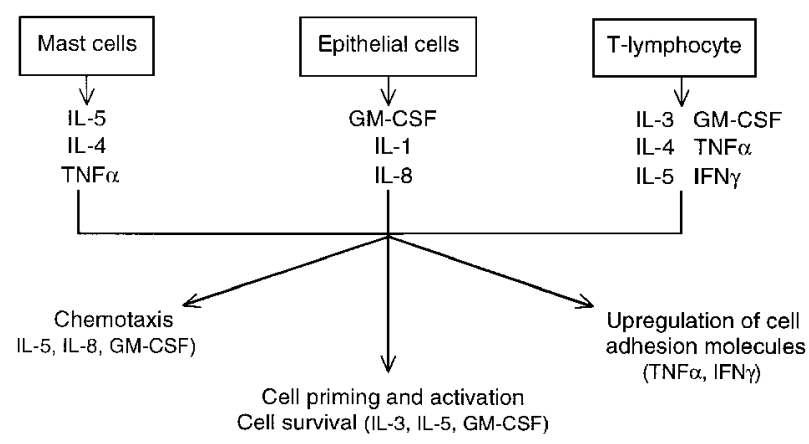

FIG. 3. Role of cytokines in the modulation of eosinophil function in allergy. ${ }^{71}$ 


\section{Chemokines}

Che mokines are cytokines which possess chemotactic activity, and are divided into groups depending on their structure. The two main groups are CC chemokines, where two cysteine residues are adjacent to each other (e.g. RANTES, MIP-1 $\alpha$, eotax in) and CXC chemokines, in which the two cysteine residues are separated by a third amino acid (e.g. IL-8). Some chemokines (RANTES, eotaxin) appear to be selective for eosinophils, while IL-8 has a chemotactic activity only for neutrophils (though there are reports that it also has an action on primed human eosinophils). ${ }^{128}$

The levels of RANTES, ${ }^{15,129}$ MP- $1 \alpha,{ }^{115}$ eotax in ${ }^{130}$ and IL-8 ${ }^{15,131}$ detected in nasal lavage are raised following nasal allergen challenge in man. Treatment with glucocorticoids, which inhibits inflammatory cell recruitment, abrogates these increases. ${ }^{15,132}$ Interestingly, mucosal cells obtained from the noses of subjects with allergic rhinitis show increased expression of mRNA for RANTES ${ }^{129}$ and eotaxin. ${ }^{130} \mathrm{It}$ is now generally accepted that RANTES and eotaxin are important in IL-5-mediated eosinophilia, where the latter causes the mobilisation of eosinophils into the circulation while the local release of chemokines provides a 'homing' mechansim for the migration of eosinophils into the tissues. ${ }^{128}$ How ever, no study has yet investigated the specific roles of chemokines in nasal hyperresponsiveness. Notw ithstanding, administration of RANTES into the nasal airway of subjects with alle rgic rhinitis causes an eosinophilia but not an influx of other inflammatory cells. ${ }^{133}$ However, the same study also found that, after allergen challenge, administration of RANTES also caused an influx of basophils, neutrophils, lymphocytes and monocytes, as well as causing epithelial shedding, a response similar to that observed in nasal hyperresponsiveness. It is therefore likely that chemokines have an important role in the recruitment of inflammatory cells that is observed during the development of nasal hyperresponsiveness.

\section{Nitric oxide}

Recently, a large amount of research has been carried out on the role of nitric oxide in airway disease. There is evidence that nitric oxide synthase (NOS) activity is increased in PAR $^{134}$ and in SAR. ${ }^{135,136}$ This would increase the amount of nitric oxide available to react with superoxide, generating free radicals which may contribute to the development of AHR. ${ }^{33}$ Nitric oxide may also have a role in the production of cytokines necessary for eosinophil survival, such as IL-4 and IL5. ${ }^{137}$ Therefore, one might expect inhibitors of NOS to prevent AHR, either by reducing free radical production or via the induction of eosinophil apoptosis. Paradoxically, NOS inhibitors actually induce AHR to histamine and bradykinin in both the human nasal airw ay ${ }^{138}$ (Fig. 4) and lower airways of asthmatics, ${ }^{139}$

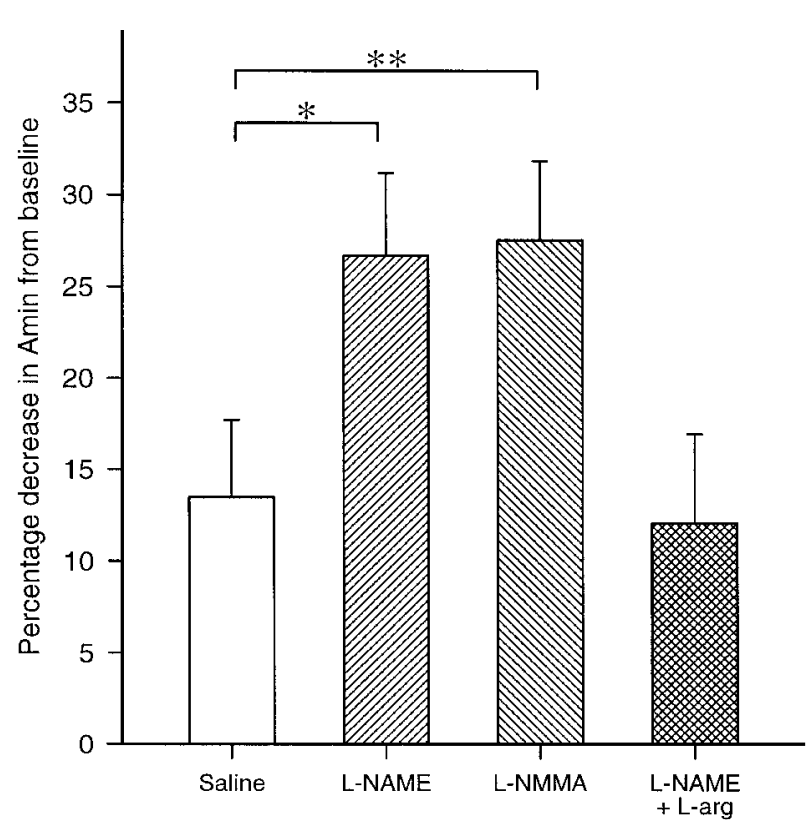

FIG. 4. The percentage decrease in the minimal crosssectional area of the nasal airway $\left(A_{\min }\right)$ from baseline $10 \mathrm{~min}$ after challenge with histamine, $200 \mu \mathrm{g}$. The nasal cavity was pretreated every $30 \mathrm{~min}$ with saline, a NOS inhibitor (L-NAME or L-NMMA, $1 \mu \mathrm{mol}$ ), or L-NAME together with L-arginine, $30 \mu \mathrm{mol}$, for $6 \mathrm{~h}$ prior to the histamine challenge. Data are means-SEM from 10 subjects. **,*Significant increase in the histamine-induced percentage change in $A_{m \text { in }}$ following pretreatment with a NOS inhibitor compared to saline pretreatment $\left({ }^{*},{ }^{*} P<0.05\right.$ and $P<0.01$, respectively, Wilcoxon sign-rank test)

and also in animal models. ${ }^{140}$ It is possible that in the normal, non-inflamed airway, nitric oxide is protective, so inhibitors of NOS would cause AHR, but in chronic airway inflammation, an inappropriate degree of nitric oxide production may be harmful and potentiate the allergic response.

Interestingly, $\mathrm{NO}$ is thought to be the central mediator of inhibitory NANC transmission. Therefore, inhibition of NOS may cause a reduction in the activity of inhibitory NANC nerves, which could cause AHR by potentiating neurogenic inflammation mediated by excitatory NANC nerves. In chronic allergy, excessive NO production could cause AHR by the formation of the peroxynitrite free radical, which causes AHR in the guinea pig airway, possibly by inhibiting cGMP production. ${ }^{33}$ Furthermore, other NO metabolites, such as nitryl chloride, can be synthesised by neutrophils, inactivating endothelial cell angiotensin-converting enzyme. ${ }^{141}$ This enzyme is involved in the degradation of kinins and possibly tachykinins in allergic rhinitis, ${ }^{102,142}$ so inhibition of this enzyme may influence AHR by potentiating the action of these mediators.

\section{Kinins}

A number of studies have identified a role for kinins in the development of AHR in the lower airways of both 
the guinea pig ${ }^{143}$ and sheep. ${ }^{144}$ Furthermore, the ability of MBP and synthetic cationic proteins to induce AHR in the lower airways of rats is dependent on the generation of kinins. ${ }^{46}$ In all three studies, administration of a bradykinin B2 receptor antagonist inhibited the development of AHR, and, where investigated, also appeared to have an effect on the recruitment of eosinophils into the airway. ECP can stimulate kallikrein activity in vitro, ${ }^{145}$ resulting in kinin production, so eosinophil-derived cationic proteins may generate kinins which lead to AHR.

Recent investigations have found that AHR in the human nasal airway may also be kinin dependent. Icatibant, a highly potent antagonist at the bradykinin B2 receptor, prevents PAF-induced AHR (Fig. 5), while PAF causes an increase in the level of kinins in nasal lavage fluid (Fig. 6). Kinins are produced in both PAR and SAR, and could therefore contribute to AHR in allergic rhinitis.

One important consideration is the source of the kinins. In SAR, antigen challenge causes an increase in plasma extravasation, so the kinins detected may be a product of plasma kallikre in activity. How ever, antigen does not induce plasma extravasection in PAR, ${ }^{5}$ and the role of plasma kallikrein has not been assessed in either allergic rhinitis or asthma. ${ }^{146}$ The levels of tissue kallikrein in nasal secretions are increased in allergic rhinitis, ${ }^{147}$ but it is not thought that tissue kallikrein can be activated by cationic proteins. ${ }^{46} \mathrm{~A}$ novel solution to this anomaly is as follows. Neutrophils

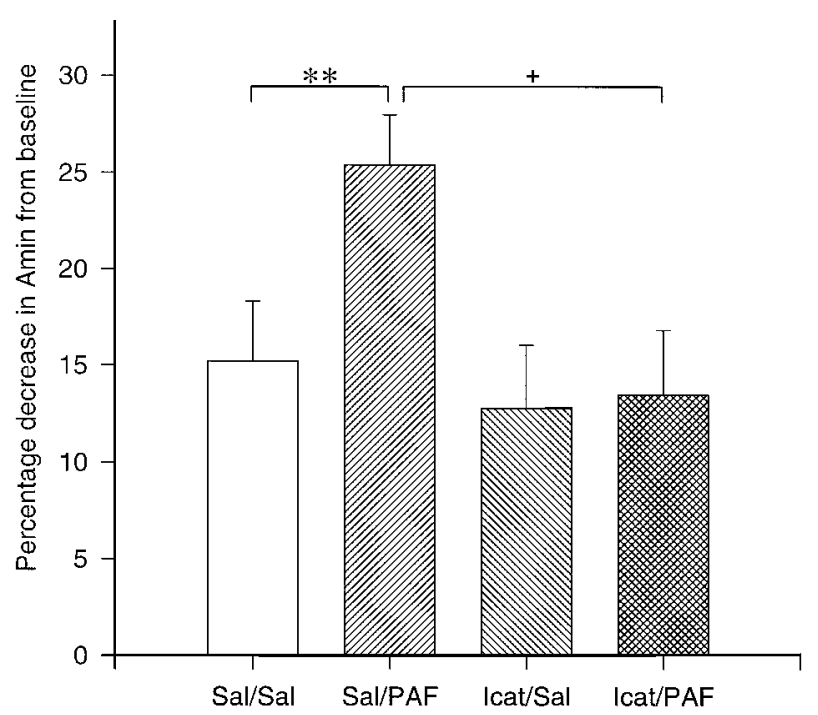

FIG. 5. The percentage decrease in the minimal crosssectional area of the nasal airway $\left(A_{\min }\right)$ from baseline $10 \mathrm{~min}$ after challenge with histamine, $200 \mu \mathrm{g}$. The nasal cavity was pretreated with saline (Sal), icatibant (Icat), $200 \mu \mathrm{g}$, and/or PAF, $60 \mu \mathrm{g}, 6 \mathrm{~h}$ prior to the histamine challenge. Data are means-SEM from 15 subjects. **, Significant increase in the histamine- induced percentage change in $A_{\min }$ following saline/PAF pretreatment compared to pretreatment with saline only ${ }^{*} P<0.01$, Wilcoxon signrank test) or icatibant/PAF $\left({ }^{+} P<0.05\right.$, Wilcoxon sign-rank test).

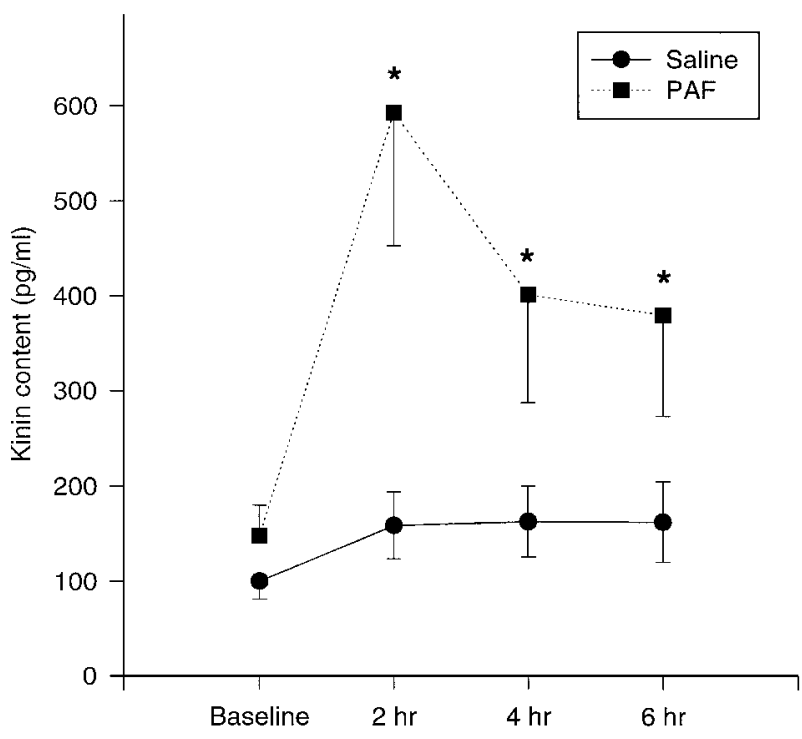

FIG. 6. The effect of PAF on the concentration of kinins in nasal lavage fluid. The nasal airway was challenged with either saline or PAF, $60 \mu \mathrm{g}$, and the airway was lavaged 2, 4 and $6 \mathrm{~h}$ after challenge. Data are means-SEM from 13 subjects. ${ }^{*}$ Significant increase $(P<0.05)$ in levels of kinin following challenge with PAF compared to saline (Wilcoxon sign-rank test).

contain tissue kallikrein and bind plasma kallikrein, together with high-and low-molecular weight kininogen, on the cell surface. ${ }^{148,149}$ Antigen and PAF challenge cause a neutrophilia in addition to eosinophil recruitment,${ }^{54}$ therefore neutrophils may provide the components needed for the generation of kinins.

The mechanism by which kinins induce AHR remains unknown. Exogenous kinins applied to the airways do not cause AHR in animal models ${ }^{46}$ nor in the human nasal airways (Turner \& Foreman, unpublished data), though one study found that bradykinin can produce AHR to acetylcholine in the guinea pig airw ay. ${ }^{150}$ Bradykinin causes sensitisation of C-fibres in the guinea pig trachea, ${ }^{151}$ and there is evidence that in the human nose enhanced responsiveness to bradykinin is mediated by neural reflexes. ${ }^{15}$ Bradykinin can also release sub $\mathrm{P}$ and other neuropeptides from sensory nerve endings, ${ }^{98,152}$ so it may induce AHR by a neuropeptide-dependent mechanism. How ever, although administration of PAF into the human nose causes kinin generation, there is no increase in sub $P$ release. Alternatively, bradykinin can initiate the production of the cytokines IL-1, IL- 6 and IL- 8 in vivo ${ }^{153}$ and stimulate the release of TNF $\alpha / \beta$ and IL-1 from macrophages. ${ }^{154}$ These cytokines may contribute to AHR as previously mentioned. Interestingly, the eosinophilia induced by antigen challenge in the lower airway of the guinea pig is reduced by bradykinin receptor antagonists ${ }^{143}$ or an inhibitor of tissue kallikrein, ${ }^{155}$ thus providing evidence for the involvement of kinins in the recruitment of eosinophils following exposure to allergen. 


\section{The role of inflammatory cells in hyperresponsiveness}

From the evidence presented, it might appear that eosinophils have a vital role in the development of AHR. However, the relationship between eosinophil activation and AHR remains controversial. Certainly, eosinophils are involved in the late response, but the development of AHR may not be dependent on the presence of eosinophils. Studies conducted in animal models indicate that AHR can occur without a detectable eosinophilia, and vice versa. ${ }^{156}$ Data obtained from studies in the human nose similarly imply that AHR does not necessarily occur together with eosinophil activation, ${ }^{48,49}$ while antigen can induce an eosinophilia without causing AHR. ${ }^{157}$ There are a range of airway inflammatory conditions which feature an eosinophilic infiltration, but no associated AHR. ${ }^{22}$ Nonetheless, the close association between eosinophil recruitment, activation and AHR in many studies $35,52,67$ implies, at the very least, that eosinophils may contribute to the development of AHR.
Although eosinophils are the main cells which have been implicated in the mechanism underlying AHR, it is likely that other cells are involved, including neutrophils, T-lymphocytes, macrophages, B-cells and basophils. ${ }^{71}$ Basophils, which may be involved in the late allergic response, are capable of generating histamine, bradykinin, MBP, $\mathrm{LTC}_{4}$, IL-4 and IL- $8,{ }^{71,158}$ which may contribute to AHR. Macrophages may also be involved in the development of nasalAHR, possibly by generating cytokines and free radicals. ${ }^{159}$

The involvement of the neutrophil in AHR is often overlooked, yet there is a wealth of evidence for an active role. Not only may they contribute to the generation of kinins and cause tissue damage via the superoxide burst, but they also generate PAF, $\mathrm{LTB}_{4}$ and a variety of cytokines. It is interesting to note that ECP has now been detected in neutrophils. ${ }^{160} \mathrm{Neu}-$ trophils isolated from atopic subjects have an increased capacity for myeloperoxidase release, and this enzyme can generate nitric oxide-derived oxidants, which can induce AHR and inhibit kininase II, an enzyme responsible for the metabolism of

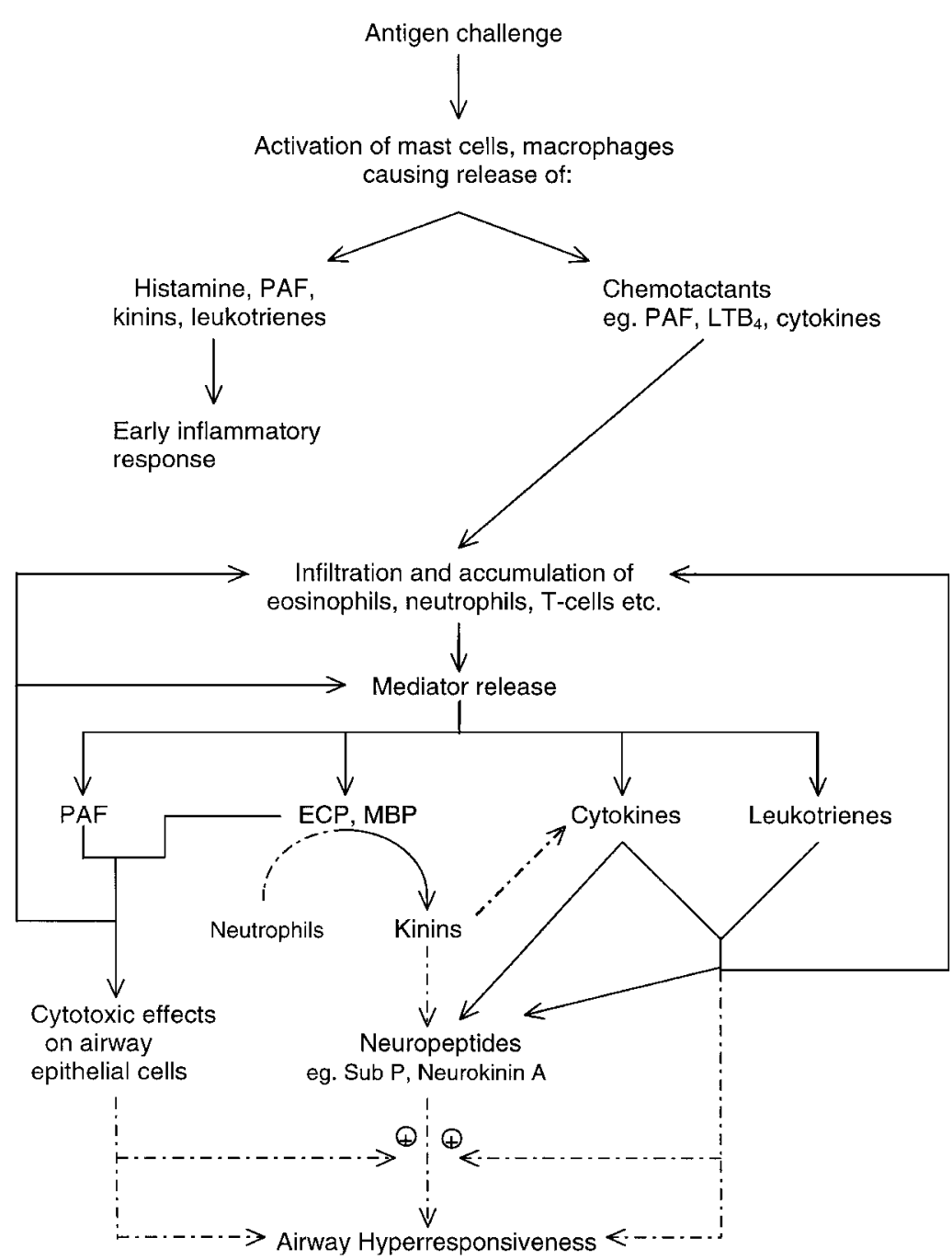

FIG. 7. Putative mechanism for the development of airway hyperresponsiveness. 
kinins. ${ }^{141}$ The hypothesis that both neutrophils and eosinophils act together in causing AHR is one which warrants further investigation.

The upregulation of ICAM-1 and VCAM-1 by cytokines in allergic rhinitis has already been discussed. ICAM-1 and VCAM-1, present on endothelial cells, bind respectively to integrins LFA-1 ( $\alpha L \beta 2$ integrin) and VLA 4 ( $\alpha 4 \beta 1$ integrin) on leukocytes, allowing leukocytes to adhere to the endothelium prior to migration. The interaction be tw een VCAM-1 and VLA4 appears to be particularly important in eosinophil migration, as neutrophils do not have the VLA-4 receptor on their surface. ${ }^{161}$ Interfering with the VCAM-1/VLA-4 pathway may, therefore, prevent eosinophil-dependent hyperresponsiveness. Monoclonal antibodies (mAbs) to the integrin sub-unit $\alpha 4$ have been developed which abolish antigen-induced hyperresponsiveness in the lower airways of a number of animal models of airway allergy. ${ }^{162-164}$ Interestingly, this effect was not always associated with an decrease in the airway eosinophilia, ${ }^{163,165}$ possibly because other mechanisms exist (e.g. via ICAM-1) whereby eosinophil migration may occur. Further development of these mAbs may provide a useful therapeutic intervention for airway allergy in man.

\section{Summary}

It would appear that a number of mediators are capable of inducing AHR in the human nasal airway, perhaps acting via different mechanisms, which would help explain the conflicting evidence regarding a role for eosinophils or airway epithelial damage in this process. However, the fact that inhibitors of leukotrienes, PAF, kinins and tachykinins can all inhibit antigen-induced AHR implies that the re may be a central common pathway in the pathogenesis of AHR. Since neurogenic inflammation can potentially be modulated by all of these mediators, neuropeptides may be involved in the final stage of AHR induction, perhaps as shown in Fig. 7. Antagonists of these mediators appear to inhibit the development of hyperresponsiveness in animals, and the development of similar antagonists for use in man may provide new pharmacological treatments for allergic rhinitis, and perhaps for other allergic airway diseases as well.

\section{References}

1. British Society for Allergy and Clinical Immunology ENT Sub-committee: Guidelines on the management of rhinitis. London, 1994.

2. Pretolani M, Vargaftig BB. From lung hypersensitivity to bronchial hyperreactivity - what can we learn from studies on animal models? Biochem Pharmacol 1993; 45: 791-800.

3. Persson CGA, Erjefalt JS, Korsgren M, Sundler F. The mouse trap. Trends Pharmacol Sci 1997; 18: 465-467.

4. Naclerio RM, Meier HL, Kagey-Sobotka A et al. Mediator release after nasal airway challenge with allergen. Am Rev Respir Dis 1983; 128: 597-602.

5. Dear JW. The bradykinin receptor in the human nasal airway: its characteristics and role in allergic rhinitis. University of London ( $\mathrm{PhD}$ Thesis), 1996.
6. Maruo K, Akaike T, Matsumura Y et al. Triggering of the vascular permeability reaction by activation of the Hageman factor-prekallikrein system by house dust mite proteinase. Biochim Biophys Acta 1991; 1074: 62-68.

7. Stewart GA, Thompson PJ, McWilliam AS. Biochemical properties of aeroallergens: contributory factors in allergic sensitisation? Pediatr Allergy Immunol 1993; 4: 163-172.

8. Druce HW, Wright RH, Kossof D, Kaliner MA. Cholinergic nasal hyperreactivity in atopic subjects. J Allergy Clin Immunol 1985; 76: 445-452.

9. Mullins RJ, Olson LG, Sutherland DC. Nasal histamine challenges in symptomatic allergic rhinitis. J Allergy Clin Immunol 1989; 83: 955-959.

10. Van Wijk RG, Zijlstra FJ, Van Toorenenbergen AW, Vermeulen A, Dieges $\mathrm{PH}$. Isolated early response after nasal allergen challenge is sufficient to induce nasal hyperreactivity. Ann Allergy 1992; 69: 43-47.

11. Aizaw a H, Miyazaki N, Shigematsu N, Tomooka M. A possible role of airw ay epithelium in modulating hyperresponsiveness. Br J Pharmacol 1988; 93: 139-145.

12. Laitinen LA, Heino M, Laitinen A, Kava T, Haahtela T. Damage of the airw ay epithelium and bronchial reactivity in patients with asthma. $\mathrm{Am}$ Rev Respir Dis 1985; 131: 599-606.

13. Ohashi Y, Nakai Y, Morimoto $\mathrm{K}$ et al. Platelet activating factor compromises airway epithelial defense functions. J Allergy Clin Immunol 1997; 100: 520-526.

14. Hulsmann AR, Raatgeep HR, den Hollander JC et al. Ox idative epithelial damage produces hyperresponsiveness of human peripheral airways. Am J Respir Crit Care Med 1994; 149: 519-525.

15. Riccio MM, Proud D. Evidence that enhanced nasal reactivity to bradykinin in patients with symptomatic allergy is mediated by neural reflexes. J Allergy Clin Immunol 1996; 97: 1252-1263.

16. Svensson C, Andersson M, Greiff L, Persson CG. Nasal mucosal endorgan hyperresponsiveness. Am J Rhinol 1998; 12: 37-43.

17. Holroyde MC. The influence of epithelium on the responsiveness of guinea-pig isolated trachea. Br J Pharmacol 1986; 87: 501-507.

18. Devillier P, Advenier C, Drapeau G, Marsac J, Regoli D. Comparison of the effects of epithelium re moval and of an enkephalinase inhibitor on the neurokinin-induced contractions of guinea-pig isolated trachea. $\mathrm{Br}$ J Pharmacol 1988; 94: 675-684.

19. Sparrow MP, Omari TI, Mitchell HW. The epithelial barrier and airway responsiveness. Can J Physiol Pharmacol 1995; 73: 180-190.

20. Advenier C, Devillier P, Matran R, Naline E. Influence of epithelium on the responsiveness of guinea-pig isolated trachea to adenosine. $\mathrm{Br} J$ Pharmacol 1988; 93: 295-302.

21. Koga Y, Satoh S, Sodeyama N, Hashimoto Y, Yanagisaw a T, Hirshman CA Role of acetylcholinesterase in airway epithelium-mediated inhibition of acetylcholine-induced contraction of guinea-pig isolated trachea. Eur J Pharmacol 1992; 220: 141-146.

22. Butterfield JH, Leiferman KM. Eosinophilassociated disease. In: Smith $\mathrm{H}$, Cook RM, eds Immunopharmacology of Eosinophils. London: Academic Press, 1993; 151-192.

23. Coyle AJ, Ackerman SJ, Irvin CG. Cationic proteins induce airway hyperresponsiveness dependent on charge interactions. Am Rev Respir Dis 1993; 147: 896-900.

24. White MV. Nasal cholinergic hyperresponsiveness in atopic subjects studied out of season. J Allergy Clin Immunol 1993; 92: 278-287.

25. Van Megen YJB, Klaassen ABM, Rogrigues de Miranda JF, van Ginneken CAM, Wentges BTR. Alte rations of muscarinic ace tylcholine receptors in the nasal mucosa of alle rgic patients in comparison with nonallergic individuals. J Allergy Clin Immunol 1991; 87: 521-529.

26. Van Megen YJB, Klaassen ABM, Rogrigues de Miranda JF, van Ginneken CAM, Wentges BTR. Alterations of adrenoceptors in the nasal mucosa of allergic patients in comparison with nonallergic individuals. J Allergy Clin Im munol 1991; 87: 530-540.

27. Lacroix JS, Kurt AM, Pochon N, Bretton C, Lundberg JM, Deshusses J. Neutral endopeptidase activity and concentration of sensory neuropeptide in the human nasal mucosa. Eur Arch Otorhinolaryngol 1995; 252: $465-468$

28. Elrod KC, Moore WR, Abraham WM, Tanaka RD. Lactoferrin, a potent tryptase inhibitor, abolishes late-phase airway responses in allergic sheep. Am J Respir Crit Care Med 1997; 156: 375-381.

29. Molinari JF, Scuri M, Moore WR, Clarke J, Tanaka RD, Abraham WM Inhaled tryptase causes bronchoconstriction in sheep via histamine release. Am J Respir Crit Care Med 1996; 154: 649-653.

30. Johnson PR, Ammit AJ, Carlin SM, Armour CL, Caughey GH, Black JL. Mast cell tryptase potentiates histamine-induced contraction in human sensitized bronchus. Eur Respir J 1997; 10: 38-43.

31. Teixeira MM, Gristwood RW, Cooper N, Hellewell PG. Phosphodiester ase (PDE) 4 inhibitors: Anti-inflammatory drugs of the future? Trends Pharmacol Sci. 1997; 18: 164-170.

32. Harbinson PL, MacLeod D, Hawksworth R et al. The effect of a novel orally active selective PDE4 isoenzyme inhibitor (CDP840) on allergeninduced responses in asthmatic subjects. Eur Respir J 1997; 10: 1008-1014

33. Sadeghi-Hashjin G, Folkerts G, Henricks PAJ et al. Peroxynitrite induces airway hyperresponsiveness in guinea pigs in vitro and in vivo. Am J Respir Crit Care Med 1996; 153: 1697-1701. 
34. Kips JC, Le febvre RA, Peleman RA, Joos GF, Pauwels RA. The effect of a nitric oxide synthase inhibitor on the modulation of airw ay responsiveness in rats. Am J Respir Crit Care Med 1995; 151: 1165-1169.

35. Bascom R, Pipkorn U, Proud D et al. Major basic protein and eosinophil-derived neurotoxin concentrations in nasal lavage fluid after antigen challenge: effect of syste mic corticosteroids and relationship to eosinophil influx. J Allergy Clin Imm unol 1989; 84: 338-346.

36. Svennson C, Andersson M, Persson CGA, Venge P, Alkner U, Pipkorn U. Albumin, bradykinin, and eosinophil cationic protein on the nasal mucosal surface in patients with hay fever during natural allergen exposure. J Allergy Clin Immunol 1990; 85: 828-833.

37. Knani J, Campbell A, Enander I, Peterson CGB, Michel F-B, Bousquet J. Indirect evidence of nasal inflammation assessed by titration of inflammatory mediators and enumeration of cells in nasal secretions of patients with chronic rhinitis. J Allergy Clin Immunol 1992; 90 $880-889$.

38. Kato M, Hattori T, Kitamura M, Beppu R, Yanagita N, Nakashima I. Major basic protein and topical administration of ke totifen in pollinosis under natural allergen provocation. ORL 1995; 57: 269-272.

39. Nishioka K, Ogawa T, Saito C et al. Major basic protein, eosinophil cationic protein, and arylsulfatase in nasal secretions of patients with japanese cedar pollinosis. Acta Med Okayama 1995; 49: 29-33.

40. Gleich GJ, Abu-Ghazaleh RA, Glitz DG. Eosinophil granule proteins structure and function. In: Gleich GJ, Kay AB, eds. Eosinophils in Allergy and Inflammation. New York: Marcel Dekker, 1994; 1-18.

41. Shin MH, Averill FJ, Hubbard WC et al. Nasal allergen challenge generates 1-O-hexadecyl-2-lyso-s $n$-glycero-3-phosphocholine. Am J Respir Crit Care Med 1994; 149: 660-666.

42. Flavahan NA, Slifman NR, Gleich GJ, Vanhoutte PM. Human eosinophil major basic protein causes hyperreactivity of respiratory smooth muscle. Role of the epithelium. Am Rev Respir Dis 1988; 138 685-688.

43. Gleich GJ. The eosinophil and asthma. In: Morley J, Colditz I, eds. Eosinophils in Asthma. London: Academic Press, 1989; 259-266.

44. Gundel RH, Letts LG, Gleich GJ. Human eosinophil major basic protein induces airway constriction and airway hyperresponsiveness in primates. J Clin Invest 1991; 87: 1470-1473.

45. Coyle AJ, Perretti F, Manzini S, Irvin CG. Cationic protein-induced sensory nerve activation: role of substance $\mathrm{P}$ in airway hyperresponsiveness and plasma extravasation. J Clin Invest 1994; 94: 2301-2306.

46. Coyle AJ, Ackerman SJ, Burch RM, Proud D, Irvin CG. Human eosinophilgranule major basic protein and synthetic polycations induce airway hyperresponsiveness in vivo dependent on bradykinin generation. J Clin Invest 1995; 95: 1735-1740.

47. Linder A, Venge P, Deuschl H. Eosinophil cationic protein and myeloperoxidase in nasal secretions as markers of inflammation in allergic rhinitis. Allergy 1987; 42: 583-590.

48. Andersson M, Andersson P, Venge P, Pipkorn U. Eosinophils and eosinophil cationic protein in nasal lavages in allergen-induced hyperresponsiveness: effects of topical glucocorticosteroid treatment. Allergy 1989; 44: 342-348.

49. Klementsson H, Venge P, Andersson M, Pipkorn U. Allergen-induced changes in nasal secretory responsiveness and eosinophil granulocytes. Acta Otolaryngol. (Stockholm) 1991; 111: 776-784.

50. Barnes PJ, Chung KF, Page CP. Platelet-activating factor as a mediator of allergic disease. J Allergy Clin Im munol 1988; 81: 919-934.

51. Andersson M, Pipkorn U. The effect of platelet activating factor on nasal hypersensitivity. Eur J Clin Pharmacol 1988; 35: 231-235.

52. Austin CE, Foreman JC. The effect of platelet activating factor on the responsiveness of the human nasal mucosa. Br J Pharmacol 1993; 110 113-118.

53. Tedeschi A, Milazzo N, MiadonnaA. Nasal eosinophilia induced by PAFacether is accompanied by the release of eosinophil cationic protein. Eur Respir J 1994; 7: 1445-1451.

54. Tedeschi A, Palumbo G, Milazzo N, Miadonna. A nasal neutrophilia and eosinophilia induced by challenge with platelet activating factor. $J$ Allergy Clin Im munol 1994; 93: 526-533.

55. Miadonna A, Tedeschi A, Arnoux B, Sala A, Zanussi C, Benveniste J. Evidence of PAF-acether metabolic pathway activation in antigen challenge on upper respiratory airways. Am Rev Respir Dis 1989; 140: $142-147$.

56. Tsai JJ, Ho CY, Wang SR. Relationship between nasal resistance and airway hyperreactivity following nasal provocation with Dermatophagoides pteronyssinus in allergic rhinitis. Int Arch Allergy Immunol 1995; 106: 286-290.

57. Touqui L, Herpin-Richard N, Gene RM et al. Excretion of platelet activating factor-acetylhydrolase and phospholipase A2 in to nasal fluids after allergenic challenge: possible role in the regulation of platelet activating factor release. I Allergy Clin Imm unol 1994; 94: 109-119.

58. Hwang SB, Lam MH, Shen TY. Specific binding sites for platelet activating factor in the human lung. Biochem Biophys Res Co $\mathrm{mm} \mathrm{1985;}$ 128: $972-979$.

59. Arima M, Manaka K, Fukuda T, Makino S. Role of platelet-activating factor in the release of neutrophil and eosinophil chemotactic attractants from cultured guinea-pig tracheal epithelial cells. Int Arch Allergy Immunol 1995; 108 (Suppl 1): 19-24.
60. Soler M, Sielczak MW, Abraham WM. A PAF antagonist blocks antigeninduced airw ay hyperresponsiveness and inflammation in sheep. JAppl Physiol 1989; 67: 406-413.

61. Coyle AJ, Page CP, Atkinson L, Sjoerdsma K, Touvay C, Metzger WJ. Modification of allergen-induced airway obstruction and airway hyperresponsiveness in an allergic rabbit model by the selective plateletactivating factor antagonist, BN 52021. J Allergy Clin Im munol 1989; 84: $960-967$.

62. Ishida K, Thomson RJ, Beattie LL, Wiggs B, Schellenberg RR. Inhibition of antigen-induced airw ay hyperresponsiveness, but not acute hypoxia nor airw ay eosinophilia, by an antagonist of platelet activating factor. $J$ Im munol 1990; 144: 3907-3911.

63. Kuitert LM, Hui KP, Uthayarkumar $S$ et al. Effect of the platelet activating factor antagonist UK-74,505 on the early and late response to allergen. Am Rev Respir Dis 1993; 147: 82-86.

64. Ganbo T, Hisamatsu K-I. Mucosal dysfunction and damage induced by platelet activating factor (PAF). Acta Otolaryngol (Stockholm) 1990; 110: $427-436$

65. Webber SE, Morikawa T, Widdicombe JG. PAF-induced muscarinic cholinoceptor hyperresponsiveness of ferret tracheal smooth muscle and gland secretion in vitro. Br J Pharmacol 1992; 105: 230-237.

66. Naclerio RM, Proud D, Togias A et al. Inflammatory mediators in late antigen-induced rhinitis. New Engl J Med 1985; 313: 65-70.

67. De Graaf-in 't Veld C, Garrelds IM, Koenders S, Gerth van Wijk R Relationship between nasal hyperreactivity, mediators and eosinophils in patients with perennial allergic rhinitis and controls. Clin Exp Allergy 1996; 26: 903-908.

68. Wang CG, Du T, Xu LJ, Martin JG. Role of leukotriene D4 in allergeninduced increases in airway smooth muscle in rat. Am Rev Respir Dis 1993; 148: 413-417.

69. Christie PE, Haw ksworth R, Spur BW, Lee TH. Effect of indomethacin on leukotriene $\mathrm{E}_{4}$-induced histamine hyperresponsiveness in asthmatic subjects. Am Rev Respir Dis 1992; 146: 1506-1510.

70. Knapp HR. Reduced allergen-induced nasal congestion and leukotriene synthesis with an orally active 5-lipoxygenase inhibitor. New EnglJ Med 1990; 323: 1745-1748.

71. Howarth PH. The cellular basis for allergic rhinitis. Allergy 1995; 50 (Suppl 23): 6-10.

72. Fischer AR, McFadden CA, Frantz R et al. Effect of chronic 5-lipoxygenase inhibition on airway hyperresponsiveness in asthmatic subjects. Am J Respir Crit Care Med 1995; 152: 1207-1207.

73. Obata T, Yamashita N, Nakagawa T. Leukotriene and thromboxane antagonists. Clin Rev Allergy 1994; 12: 79-93.

74. Hamilton A, Faiferman I, Stober P, Watson RM, O’Byrne PM. Pranlukast, a cyste inyl leukotriene receptor antagonist, attenuates allergen-induced early-and late-phase bronchoconstriction and airway hyperresponsiveness in asthmatic subjects. J Allergy Clin Immunol 1998; 102: $177-183$.

75. Turner CR, Breslow R, Conklyn MJ et al. In vitro and in vivo effects of leukotriene $\mathrm{B}_{4}$ antagonism is a primate model of asthma.J Clin Invest 1996; 97: 381-387.

76. Seeds EA, Kilfeather S, Okiji S, Schoupe TS, Donihi-Gale D, Page CP. Role of lipoxygenase metabolites in platelet activating factor-and antigeninduced bronchial hyperresponsiveness and eosinophil infiltration. Eur J Pharmacol 1995; 293: 369-376.

77. Weller PF Lipid, peptide and cytokine mediators elaborated by eosinophils. In: Smith H, Cook RM, eds Immunopharmacology of Eosinophils. London: Academic Press, 1993; 25-42.

78. Sugimo to M, Sugiyama S, Yanagita N, Ozawa T. Laser high performance liquid chromatography determination of prostaglandins in nasal lavage fluid in allergic rhinitis. Clin Exp Allergy 1994; 24: 324-329.

79. Wagenmann M, Baroody FM, Desrosiers $M$ et al. Unilateral nasal allergen challenge leads to bilateral release of prostaglandin $\mathrm{D}_{2}$. Clin Exp Allergy 1996; 26: 371-378.

80. Ramis I, Catafau JR, Serra J, Bulbena O, Picado C, Gelpi E. In vivo rele ase of 15-HETE and other arachidonic acid metabolites in nasal secretions during early allergic reactions. Prostaglandins 1991; 42: 411-420.

81. Folkerts G, Nijkamp FP. Airway epithelium: more than just a barrier! Trends Pharmacol Sci 1998; 19: 334-341.

82. Chung KF, Aizaw a H, Leikauf GD, Ueki IF, Evans TW, Nadel JA. Airway hyperresponsiveness induced by platelet-activating factor: role of thromboxane generation. J Pharmacol Exp Ther 1986; 236: $580-584$.

83. Lanes S, Stevenson JS, Codias E et al. Indomethacin and FPL-5723 inhibit antigen-induced airway hyperresponsiveness in sheep. $J A p p l$ Physiol 1986; 61: 864-872.

84. Jones GL, Saroea HG, Watson RM, O'Byrne PM. Effect of an inhaled thromboxane mimetic (U46619) on airway function in human subjects. Am Rev Respir Dis 1992; 145: 1270-1274.

85. Itoh K, Takahashi E, Mukaiyama O, Satoh Y, Yamaguchi T. Effects of a thromboxane synthase inhibitor (CS-518) on the eosinophil-dependent late asthmatic response and airway hyperresponsiveness in guinea pigs. Int Arch Allergy Im munol 1996; 109: 79-84.

86. Metwali A, Blum AM, Ferraris L, Klein JS, Fiocchi C, Weinstock JV. Eosinophils within the healthy or inflammed human in testine produce substance $\mathrm{P}$ and vasoactive intestinal peptide. J Neuroimmunology 1994; 52: 69-78. 
87. Mosimann BL, White MV, Hohman RJ, Goldrich MS, Kaulbach HC Kaliner M. Substance P, calcitonin gene-related peptide, and vasoactive intestinal peptide increase in nasal secretions after allergen challenge in atopic patients. J Allergy Clin Im munol 1993; 92: 95-104.

88. Ladenius ARC, Biggs DF. Capsaicin prevents the induction of airway hyperresponsiveness in a guinea pig model of asthma. Am Rev Respir Dis 1989; 139: A232.

89. Matsuse T, Thomson RJ, Chen XR, Salari H, Schellenberg RR. Capsaicin inhibits airway hyperresponsiveness but not lipoxygenase activity or eosinophilia after repeated aerolised antigen in guinea pigs. Am Rev Respir Dis 1991; 144: 368-372.

90. Numao T, Agrawal DK. Neuropeptides modulate human eosinophil chemotaxis. J Im munol 1992; 149: 3309-3315.

91. Van Oosterhout AJ, Van-Ark I, Hofman G, Van der Linde HJ, Fattah D, Nijkamp FP. Role of interleukin-5 and substance P in development of airw ay hyperreactivity to histamine in guinea-pigs. Eur Respir J 1996; 9: 493-499.

92. Greiff L, Svensson C, Andersson M, Persson CG. Effects of topical capsaicin in seasonal allergic rhinitis. Tho rax 1995; 50: 225-229.

93. Sanico AM, Atsuta S, Proud D, Togias A. Dose-dependent effects of capsaicin nasal challenge: in vivo evidence of human airway neurogenic inflammation. J Allergy Clin Im munol 1997; 100: 632-641.

94. Philip G, Sanico AM, Togias A. Inflammatory cellular influx follows capsaicin nasal challenge. Am J Respir Crit Care Med 1996; 153: $1222-1229$

95. Stjarne P, Rinder J, Heden-Blomquist E et al. Capsaic in desensitization of the nasal mucosa reduces symptoms upon allergen challenge in patients with allergic rhinitis. Acta Otolaryngol (Stockholm) 1998 118: 235-239.

96. Zhang R, Jiang D, Li Z. Clinical observation and therapeutic mechan is of blocking agent of substance $P$ nerves in the treatment of perennial allergic rhinitis. Chung Hua Erh Pi Yen Hou Ko Tsa Chih 1995; 30: $163-165$.

97. Baumgarten CR, O'Connor A, Dokic D, Schultz KD, Kunkel G. Substance $\mathrm{P}$ is generated in vivo following nasal challenge of allergic individuals with bradykinin. Clin Exp Allergy 1997; 27: $1322-1327$.

98. Saria A, Martling CR, Yan Z, Theodorsson-Norheim E, Gamse R, Lundberg JM. Release of multiple tachykinins from capsaicin-sensitive sensory nerves in the lung by bradykinin, histamine, dimethylphenyl pipe razinium, and vagal nerve stimulation. Am Rev Respir Dis 1988; 137: $1330-1335$.

99. Okamoto Y, Shirotori K, Kudo K et al. Cytokine expression after the topical administration of substance $\mathrm{P}$ to human nasal mucosa. The role of substance P in nasal allergy. J Im munol 1993; 151: 4391-4398.

100. Kohrogi H; Yamaguchi T, Kawano O, Honda I, Ando M, Araki S. Inhibition of neutral endopeptidase potentiates bronchial contraction induced by immune response in guinea pigs in vitro. Am Rev Respir Dis 1991; 144: 636-641.

101. Crimi N, Polosa R, Pulvirenti G et al. Effect of an inhaled neutral endopeptidase inhibitor, phosphoramidon, on baseline airway calibre and bronchial responsiveness to bradykinin in asthma. Thorax 1995 ; 50: $505-510$

102. Chatelain C, Pochon N, Lacroix JS. Functional effects of phosphoramidon and captopril on exogenous neuropeptides in human nasal mucosa. Eur Arch Otorhinolaryngol 1995; 252: 83-85.

103. Ohkubo K, Okuda M, Kaliner MA. Immunological localization of neuropeptide-degrading enzymes in the nasal mucosa. Rhinology 1994; 32: $130-133$

104. Abraham WM, Ahmed A, Cortes A et al. Airway effects of inhaled bradykinin, substance $\mathrm{P}$ and neurokinin $\mathrm{A}$ in sheep. J Allergy Clin Im munol 1991; 87: 557-564.

105. Baraniuk JN, Lundgren JD, Okayama M et al. Substance P and neurokinin A in human nasal mucosa. Am J Respir Cell Mol Biol 1991; 4: $228-236$

106. Braunstein G, Fajac I, Lacronique J, Frossard N. Clinical and inflammatory responses to exogenous tachykinins in allergic rhinitis. Am Rev Respir Dis 1991; 144: 630-635.

107. Bertrand C, Geppetti P (1996): Tachykinin and kinin receptor antagonists: therapeutic perspectives in allergic airway disease. Trend Pharmacol Sci 1996; 17: 255-259.

108. Sanderson CJ. Interleukin-5 and the regulation of eosinophil production. In: Smith H, Cook RM, eds Immunopharmacology of Eosino phils. London: Academic Press, 1993; 11-24.

109. Hogan SP, Foster PS. Cytokines as targets for the inhibition of eosinophillic inflammation. Pharmacol Ther 1997; 74: 259-283.

110. Mauser PJ, Pitman A, Witt A et al. Inhibitory effect of the TRFK-5 anti-IL-5 antibody in a guinea pig model of asthma. Am Rev Respir Dis 1993; 148: $1623-1627$.

111. Boey H, Rosenbaum R, Castracane J, Borish L. Interleukin 4 is a neutrophil activator. J Allergy Clin Im munol 1989; 83: 978-984.

112. Hellquist HB, Karlsson MG. Nasal memory Tlymphocytes capable of producing IL-4 in the allergic reaction. Allergy 1992; 47: 334-336.

113. Bradding P, Feather IH, Wilson $S$ et al. Immunolocalization of cytokines in the nasal mucosa of normal and perennial rhinitic subjects. The mast cell as a source of IL 4 , IL- 5 and IL- 6 in human allergic mucosal inflammation. J Im munol 1993; 151: 3853-3865.
114. Gosset P, Malaquin F, Delneste Y et al. Interleukin-6 and interleukin-1 alpha production is associated with antigen-induced late nasal response. J Allergy Clin Im munol 1993; 92: 878-890.

115. Sim TC, Reece LM, Hilsmeier KA, Grant JA, Alam R. Secretion of chemokines and other cytokines in allergen-induced nasal responses: inhibition by topical steroid treatment. Am J Respir Crit Care Med 1995; 152: 927-933.

116. Lantero S, Sacco O, Scala C, Morelli MC, Rossi GA. Eosinophil locomotion and the release of IL-3 and IL-5 by allergen-stimulated mononuclear cells are effectively downregulated in vitro by budesonide. Clin Exp Allergy 1996; 26: 656-664.

117. GalliSJ, Gordon JR, Wershil BK et al. Mast cell and eosinophil cytokines in allergy and inflammation. In: Gleich GJ, Kay AB, eds. Eosinophils in Allergy and Inflam mation. New York: Marcel Dekker, 1994; 255-280.

118. Nonaka M, Nonaka R, Jordana M, Dolovich J. GM-CSF, IL-8, IL-1R, TNF$\alpha \mathrm{R}$ and HLA-DR in nasal epithelial cells in allergic rhinitis. Am J Resp Care Crit Med 1996; 153: 1674-1681.

119. Calde ron MA, Devalia JL, Prior AJ, Sapsford RJ, Davies RJ. A comparison of cytokine release from epithelial cells cultured from nasal biopsy specimens of atopic patients with and without rhinitis and nonatopic subjects without rhinitis. I Allergy Clin Im munol 1997; 99: 65-76.

120. Durham SR, Ying S, Varney VA. Cytokine messenger RNA expression for IL-3, IL-4, IL-5, and granulocyte/macrophage-colony-stimulating factor in the nasal mucosa after local allergen provocation: relationship to tissue eosinophilia. J Im munol 1992; 148: 2390-2394.

121. Altman LC, Ayars GH, Baker C, Luchtel DL. Cytokines and eosinophilderived cationic proteins upregulate in tracellular adhesion molecule-1 on human nasal epithelial cells. J Allergy Clin Immunol 1993; 92 527-536.

122. Wooley KL, Adekrith E, Woolley MJ, Ellis R, Jordana M, O’Byrne PM Effects of allergen challenge on eosinophils, eosinophil cationic protein, and granulocyte-macrophage colony stimulating factor in mild asthma. Am J Respir Crit Care Med 1995; 151: 1915-1924.

123. Ohnishi T, Kita H, Weiler D et al. IL-5 is the predominant eosinophilactive cytokine in the antigen-induced pulmonary late-phase reaction. Am Rev Respir Dis 1993; 147: 901-907.

124. Kraneveld LD, Nijkamp FP, Van Oosterhout AJM. Role for neurokinin-2 receptor in interleukin-5-induced airway hyperresponsiveness but not eosinophilia in guinea pigs. Am J Respir Crit Care Med 1997; 156: 367-374.

125. Selig W, Tocker J. Effect of interleukin-1 receptor antagonist on antigeninduced pulmonary responses in guinea pigs. Eur J Pharmacol 1992, 213: 331-336.

126. Tsukagoshi H, Sun J, Kwon O, Barnes PJ, Chung KF. Role of neutra endopeptidase in bronchial hyperresponsiveness to bradykinin induced by IL-1 $\beta$. I Appl Physiol 1995; 78: 921-927.

127. Tsukagoshi H, Robbins RA, Barnes PJ, Chung KF. Role of nitric oxide and superoxide anions in interleukin-1 $\beta$-induced airway hyperresponsiveness to bradykinin. Am J Respir Crit Care Med 1994; 150 1019-1025.

128. Barnes PJ, Chung KF, Page CP. Inflammatory mediators of asthma: an update. Pharmacol Rev 1998; 50: 515-596.

129. Rajakulasingam K, Hamid Q, O'Brien F et al. RANTES in human alllergen-induced rhinitis: cellular source and relation to tissue eosinophilia. Am J Respir Crit Care Med 1997; 155: 696-703.

130. Minshall EM, Cameron L, Lavigne F et al. Eotax in mRNA and protein expression in chronic sinusitis and allergen-induced nasal responses in seasonal allergic rhinitis. Am J Respir Cell Mol Biol 1997; 17: 683-690.

131. Gosset P, Tillie-Leblond L, Malaquin F, Durieu J, Wallaert B, Tonnel AB. Interleukin- 8 secretion in patients with allergic rhinitis after an allergen challenge: interleukin-8 is not the main chemotactic factor present in nasal lavage. Clin Exp Allergy 1997; 27: 379-388.

132. Meltzer EO. The pharmacological basis for the treatment of perennial allergic rhinitis and non-allergic rhinitis with topical corticosteroids. Allergy 1997; 52 (36 Suppl): 33-40.

133. Kuna P, Alam R, Ruta U, Gorski P. RANTES induces nasal mucosal inflammation rich in eosinophils, basophils and lymphocytes in vivo. Am J Respir Crit Care Med 1998; 157: 873-879.

134. Garrelds IM, Van Amsterdam JGC, De Graaf-in't Veld C, Gerth van Wijk R. Nitric oxide metabolites in nasal lavage fluid of patients $w$ ith house dust mite allergy. Thorax 1995; 50: 275-279.

135. Martin U, Bryden K, Devoy M, How arth P. Increased levels of exhaled nitric oxide during nasal and oral breathing in subjects with seasonal rhinitis. J Allergy Clin Im munol 1996; 97: 768-772.

136. Kharitonov SA, Rajakulasingam K, O'Connor B, Durham SR, Barnes PJ Nasal nitric oxide is increased in patients with asthma and allergic rhinitis and may be modulated by nasal glucocorticoids. J Allergy Clin Im munol 1997; 99: 58-64.

137. Barnes PJ, Liew FY. Nitric oxide and asthmatic inflammation. Im munology Today 1995; 16: 128-130.

138. Turner PJ, Maggs JRL, Foreman JC. Inhibitors of nitric oxide synthase induce hyperresponsiveness in the human nasal airway. Allergologie 1998; 11: 559

139. Ricciardolo FL, Geppetti P, Mistretta A et al. Randomised double-blind placebo-controlled study of the effect of inhibition of nitric oxide synthesis in bradykinin-induced asthma. Lancet 1996; 348: 374-377. 
140. Nijkamp FP, Van der Linde HJ, Folkerts G. Nitric ox ide syn the sis inhibito rs induce airw ay hyperresponsiveness in the guine pig in vivo and in vitro - role of the epithelium. Am Rev Resp Dis 1993; 148: 727-734.

141. Eiserich JP, Hristova M, Cross CE et al. Formation of nitric oxide-derived inflammatory oxidants by myeloperoxidase in neutrophils. Nature 1998; 391: 393-397.

142. Lurie A, Nadel JA, Roismann Get al. Role of neutral endopeptidase and kininase II on substance-P induced increase in nasal obstruction in patients with allergic rhinitis. Am J Respir Crit Care Med 1994; 149: $113-117$.

143. Farmer SG, Wilkins DE, Meeker SA, Seeds EAM, Page CP. Effects of bradykinin receptor antagonists on antigen-induced respiratory distress, airw ay hyperresponsiveness and eosinophilia in guinea pigs. $\mathrm{BrJ}$ Pharmacol 1992; 107: 653-659.

144. Soler M, Sielczak M, Abraham WM. A bradykinin-antagonist blocks antigen-induced airway hyperresponsiveness and inflammation in sheep. Pulm Pharmacol 1990; 3: 9-15.

145. Venge P, Dahl R, Hallgren R. Enhancement of factor XII reactions by eosinophil cationic protein. Thromb Res 1979; 14: 641-649.

146. Reddigari SR, Silverberg M, Kaplan AP. Bradykinin formation in allergic diseases and hereditary angiodema. In: Farmer SJ, ed. The Kinin System. London: Academic Press, 1997; 265-285.

147. Baumgarten CR, Nichols RC, Naclerio RM, Proud D. Concentrations of glandular kallikrein in human nasal secretions increase during experimentally induced allergic rhinitis. J Immunol 1986; 137: $1323-1328$.

148. Gustafson EJ, Schmaier AH, Wachtfogel YT, Kaufman N, Kucich U Colman RW. Human neutrophils contain and bind high molecular weight kininogen. J Clin Invest 1989; 84: 28-35.

149. Henderson LM, Figueroa CD, Muller-Esterl W, Bhoola KD. Assembly of contact-phase factors on the surface of the human neutrophil membrane. Blood 1994; 84: 474-482.

150. Omini C, Burnelli G, Hernandez A, Daffonchio L. Bradykinin and substance $\mathrm{P}$ potentiate acetylcholine-induced bronchoconstriction in the guinea pig. Eur J Pharmacol 1989; 163: 195-197.

151. Fox AJ, Lalloo UG, Belvisi MG, Be rnareggi M, Fan Chung K, Barnes PJ. Bradykinin-evoked sensitisation of airw ay sensory nerves: a mechanism for ACE-inhibitor cough. Nature Med 1996; 2: 814-817.

152. Geppetti P, Tramontana M, Santicioli P, Del-Bianco E, Giuliani S, Maggi CA. Bradykinin-induced release of calcitonin gene-related peptide from capsaicin-sensitive nerves in guinea-pig atria: mechanism of action and calcium requirements. Neuroscience 1990; 38: 687-692.
153. Ferreira SH, Lorenzetti BB, Poole S. Bradykinin initiates cytokinemediated inflammatory hyperalgesia. Br J Pharmacol 1993; 110 $1227-1231$.

154. Tiffany CW, Burch RM. Bradykinin stimulates tumour necrosis factor and interleukin-1 release from macrophages. FEBS Lett 1989; 247: 189-192.

155. Evans DM, Jones DM, Pitt GR et al. Synthe tic inhibitors of human tissue kallikrein. Imm unopharmacology 1996; 32: 117-118.

156. Spina D, McKenniff MG, Coyle AJ et al. Effect of capsaicin on PAFinduced bronchial hyperresponsiveness and pulmonary cell accumulation in the rabbit. Br J Pharmacol 1991; 103: 1268-1274.

157. Seeds EA, Coyle AJ, Page CP. The effect of the selective PAF antagonis WEB 2170 on PAF and antigen-induced airw ay hyperresponsiveness and eosinophil infiltration. J Lipid Mediators 1991; 4: 111-121.

158. Costa JJ, Weller PF, Galli SJ. The cells of the allergic response. J Am Med Assoc 1997; 278: 1815-1822.

159. Bachert C, Behrendt H, Kosbusch K, Hauser U, Ganzer U. Possible role of macrophages in allergic rhinitis. Int Arch Allergy Appl Immunol 1991; 94: $244-245$.

160. Sur S, Glitz DG, Kita $\mathrm{H}$ et al. Localization of eosinophil-derived neurotoxin and eosinophil cationic protein in neutrophilic leukocytes. J Leukocyte Biol 1998; 63: 715-722.

161. Texeira MM, Williams TJ, Hellewell PG. Mechanisms and pharmacological manipulation of eosinophil accumulation in vivo. Trends Pharmacol Sci 1995; 16: 418-423.

162. Abraham WM, Ahmed A, Sielczak MW, Narita M, Arrhenius T, Elices MJ. Blockade of late-phase airway responses and airway hyperresponsiveness in allergic sheep with a small-molecule peptide inhibitor ofVLA4. Am J Respir Crit Care Med 1997; 156: 696-703.

163. Laberge S, Rabb H, Is sekutz TB, Martin JG. Role of VLA-4 and LFA-1 in allergen-induced airw ay hyperresponsiveness and lung inflammation in the rat. Am J Respir Crit Care Med 1995; 151: 822-829.

164. Kraneveld AD, van Ark I, Van Der Linde HJ, Fattah D, Nijkamp FP, Van Oosterhout AJ. Antibody to very late activation antigen 4 prevents interleukin-5-induced airway hyperresponsiveness and eosinophil infiltration in the airways of guinea pigs. J Allergy Clin Im munol 1997; 100: $242-250$.

165. Abraham WM, Sielczak MW, Ahmed A et al. Alpha 4-integrins mediate antigen-induced late bronchial responses and prolonged airway hyperresponsiveness in sheep. J Clin Invest 1994; 93: 776-787.

\section{Accepted 12 March 1999}




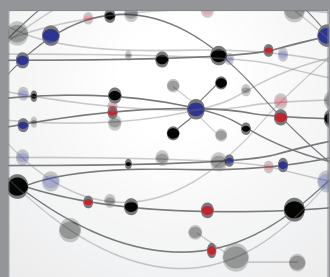

The Scientific World Journal
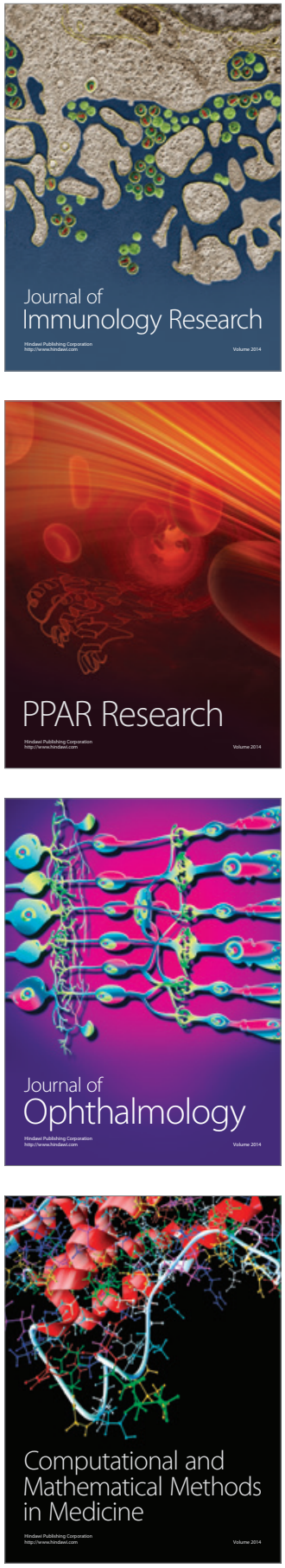

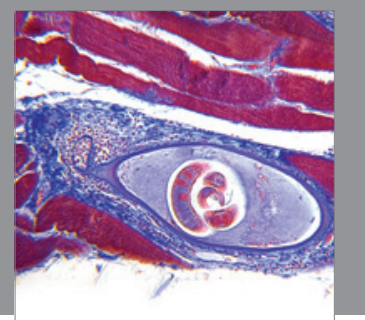

Gastroenterology

Research and Practice
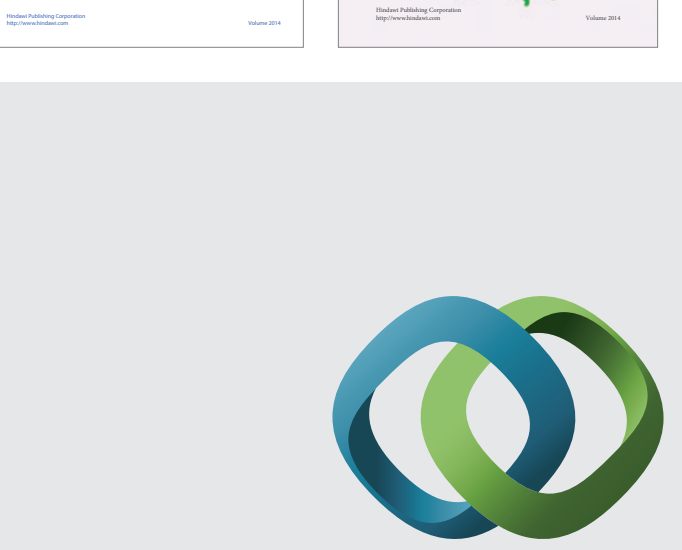

\section{Hindawi}

Submit your manuscripts at

http://www.hindawi.com
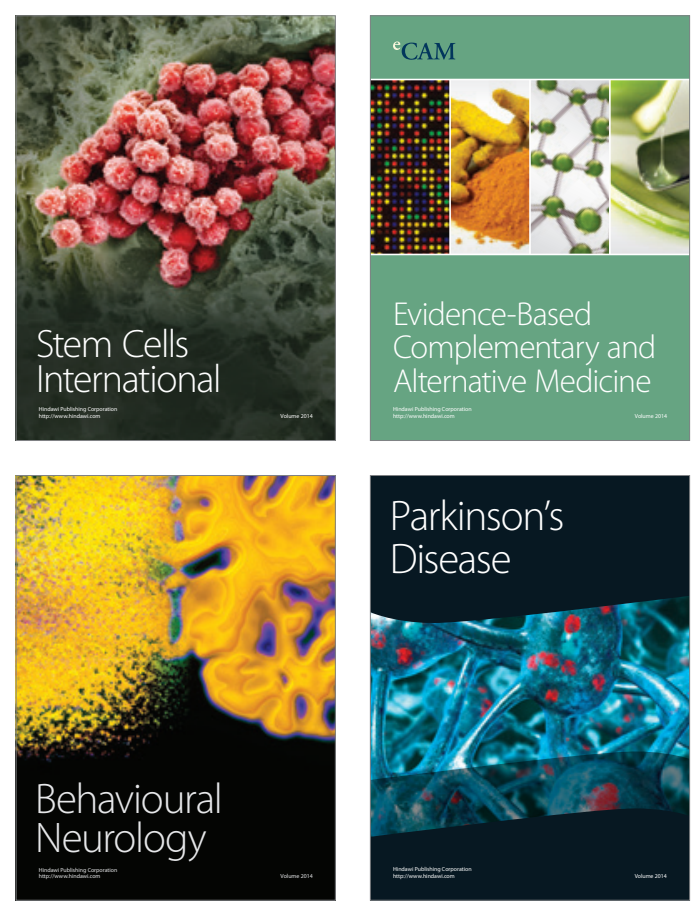

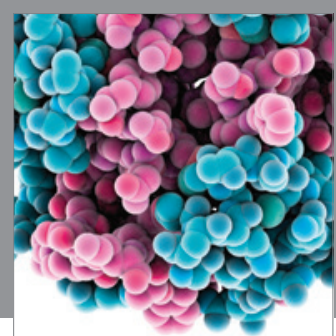

Journal of
Diabetes Research

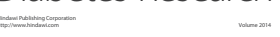

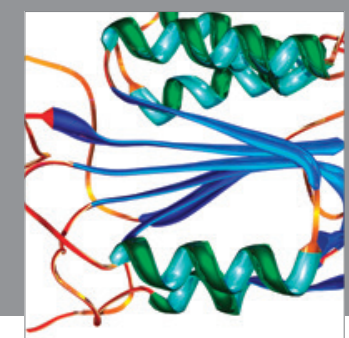

Disease Markers
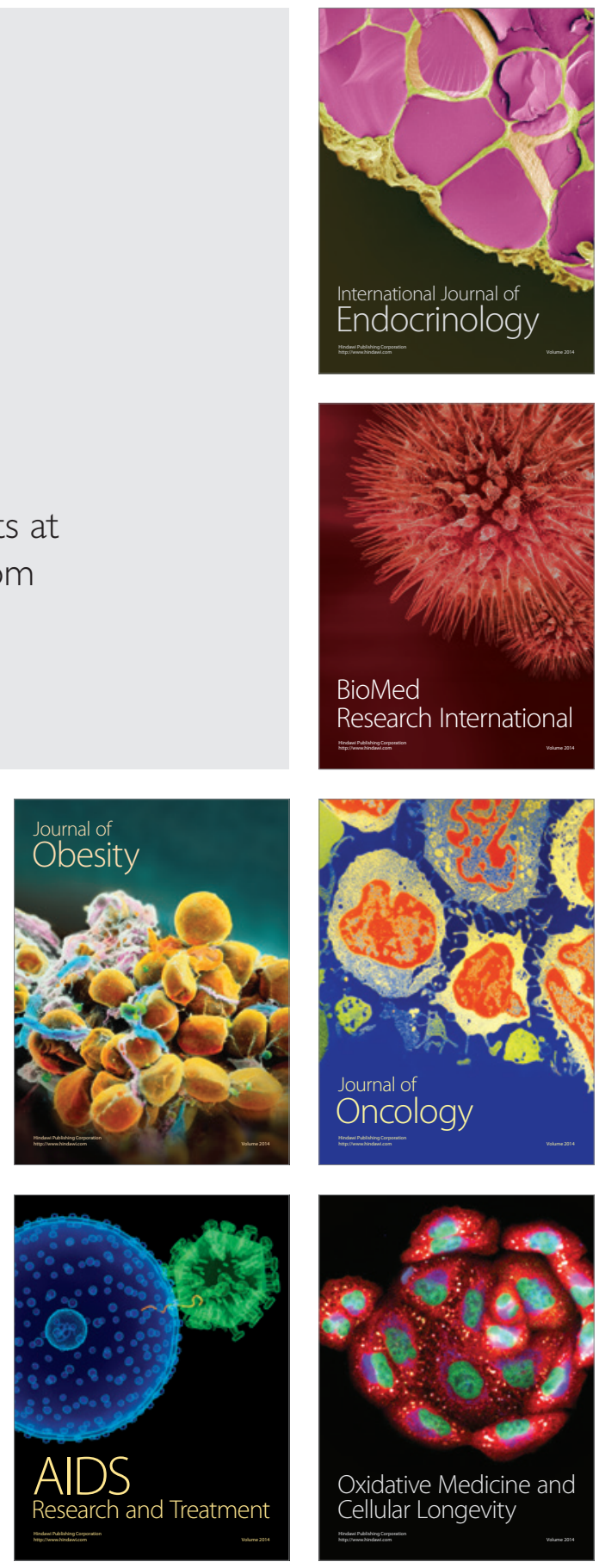